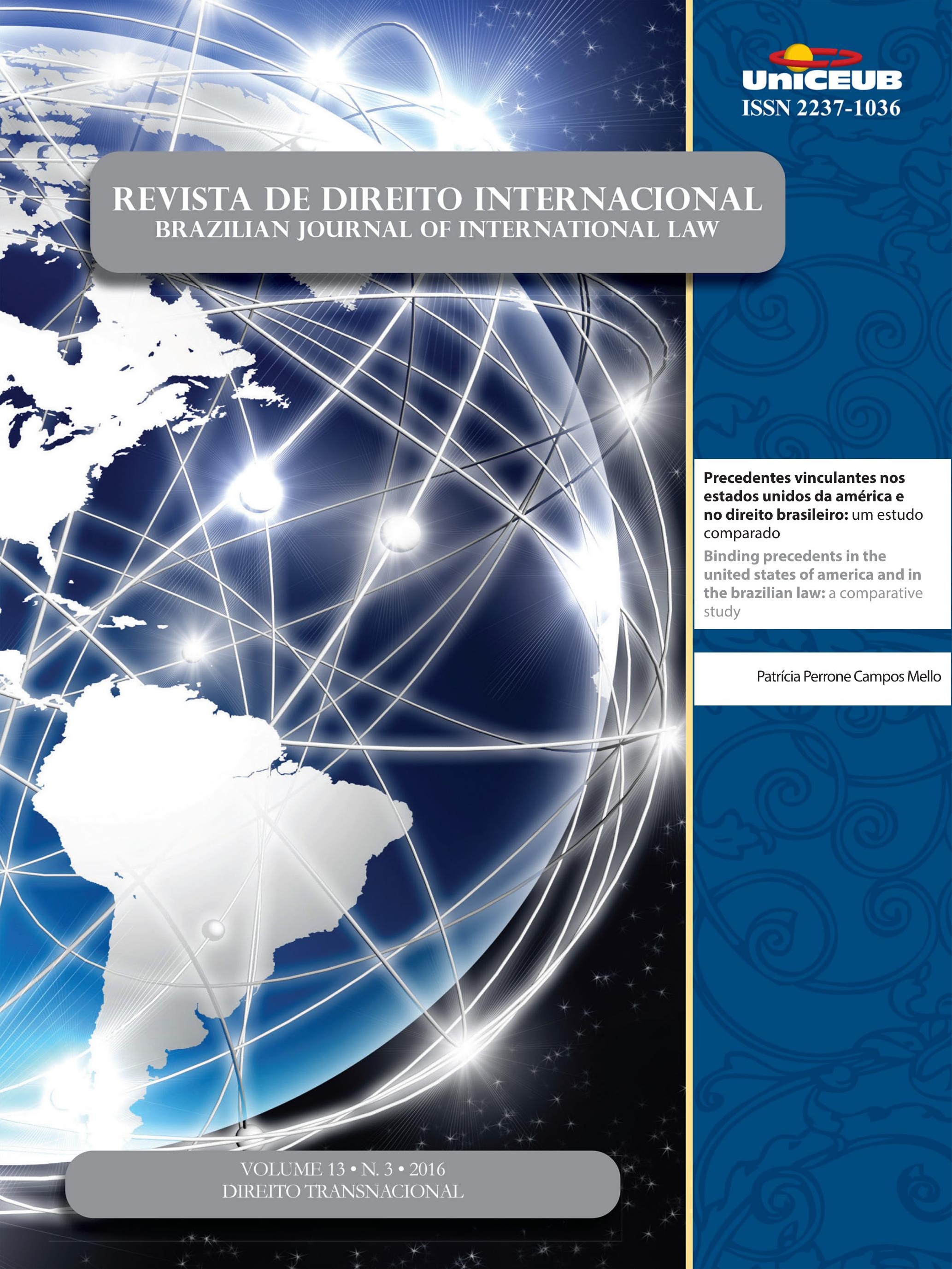


Crônicas da ATUALIdAde do direito internacional .................................................. 2

I. Dossiê Temático: Direito Transnacional .........................................................15

EDITORIAL: O Direito Transnacional - Circulação de normas e relações jurídicas transnacionais .......16 Priscila Pereira de Andrade

A emergênCia do direito transnacional ambiental .............................................18 Priscila Pereira de Andrade

Desafíos y RESPUESTAS TRANSNACIONALES FRENTE A LOS CRÍMENES AMBIENTALES ...............30 Rosmerlin Estupiñan-Silva

DiREITO TRANSNACIONAL E MUdANÇAS CLIMÁTICAS .50 Géraud de Lassus Saint-Geniès

Especies en movimiento: la Convención sobre el Comercio Internacional de Especies Amenazadas de Fauna y Flora Silvestres como espacio de “Encuentro” de discursos, ACTORES Y ESTRATEGIAS EN EL DERECHO AMBIENTAL TRASNACIONAL

María Valeria Berros e Dabel Leandro Franco

El carácter transnacional del Sistema comunitario de ECogestion « Eco-ManageMENT AND Audit SCHEME » (EMAS) DENTRo de LA UE y MÁs ALlÁ DE SUS Fronteras ......72 Adélie Pomade

O CONCEITO DE CONDUTA EMPRESARIAL RESPONSÁVEL À LUZ DOS ORDENAMENTOS JURÍDICOS BRASILEIRO, INTERNACIONAL E TRANSNACIONAL

Gabriel Webber Ziero

ARBITRAGEM NO DIREITO TRIBUTÁRIO INTERNACIONAL E NO DIREITO INTERNACIONAL DOS INVESTIMENTOS: UMA MANIFESTAÇÃO DO DIREITO TRANSNACIONAL

Vivian Daniele Rocha Gabriel 
O DIREITO TRIBUTÁRIO SOB UMA PERSPECTIVA TRANSNACIONAL

Franciele de Simas Estrela Borges

As Características do Direito Transnacional como Metodologia: Análise sob o enfoQue dos Aspectos Processuais da Arbitragem 126

Flávia Foz Mange

O DIREITO TRANSNACIONAL (“GLOBAL LAW") E A CRISE DE PARADIGMA DO ESTADO-CENTRISMO: É POSSÍVEL CONCEBER UMA ORDEM JURÍDICA TRANSNACIONAL? ...................................... 146

Luiza Nogueira Barbosa e Valesca Raizer Borges Moschen

TransPorte AÉREO E DIREITO TRANSNACIONAL: DA CONVERGÊNCIA À UNIFORMIDADE 160 Mickael R. Viglino

Outros Artigos. 175

O Fundo Monetário Internacional e a proteção dos direitos humanos: uma análise DO PROGRAMA DE CRESCIMENTO E REDUÇÃO DA POBREZA NO HAITI 177

Pablo Henrique Hubner de Lanna Costa e Carlos Alberto Simões de Tomaz

Um estranho no ninho? Padrões privados no Acordo de Barreiras Técnicas ao CoMÉRCIO DA OMC 192

Michelle Ratton Sanchez Badin e Marina Yoshimi Takitani

Os benefícios tributários do programa Inovar-Auto e os princípios da Nação Mais Favorecida e do Tratamento Nacional: uma análise dos argumentos dos Painéis atualmente em Curso contra o Brasil no Órgão de SoluÇão de Controvérsias da OMC . 211 Eric Moraes Castro e Silva

A ERA DA HUMANIDADE: REFLEXões PARA A HISTÓRIA DO DIREITO INTERNACIONAL 236 Henrique Weil Afonso

Precedentes vinculantes nos Estados Unidos da América e no direito brasileiro: Um ESTUDO COMPARADO 264

Patrícia Perrone Campos Mello 
IL DIRITTO AMBIENTALE SECONDO L'OTTICA DEL DIRITTO COSTITUZIONALE POSITIVO E LA RESPONSABILITÀ PER DANNI ALL'AMBIENTE NEL DIRITTO COMUNITARIO: LO STATO DELL'ARTE DEL DIRITTO AMBIENTALE COSTITUZIONALE E COMUNITARIO 287

Elcio Nacur Rezende

DA DESCONSIDERAÇÃo DA PERSONALIDADE JURÍDICA NAS RELAÇÕES CONSUMEIRISTAS BRASILEIRAS: ANÁLISE À LUZ DAS TEORIAS CLÁSSICAS

Daniel Amin Ferraz e Marcus Vinicius Silveira de Sá

ANALYSIS OF ADVANTAGES AND DISADVANTAGES OF FORUMS PRESCRIBED UNDER THE UNCLOS AND STATE PRACTICE: THE WAY AHEAD FOR INDIA ......................................................319

Vinai Kumar Singh

Do governo POR LEIS À governanÇA POR NúMERos: breve anÁlise do Trade in SERVICE AgreEMENT (TISA) ...............................................................................338 Jânia Maria Lopes Saldanha, Rafaela da Cruz Mello e Têmis Limberger

As DIRETIVAS EUROPEIAS COMO NORMA REGULADORA DO DIREITO ADMINISTRATIVO GLOBAL ..356 Alice Rocha da Silva e Ruth Maria Pereira dos Santos

O desenVolvimento da POlítica AGRícola COMUM dA UNião EUROPEIA 375 Tatiana de A. F. R. Cardoso Squeff

A imunidade de Jurisdição das organizaÇões internacionais FaCE AO Direito de aCESSO À JUSTIÇA 391

Fernanda Araújo Kallás e Caetano

O DIREITO INTERNACIONAL ENTRE O DEVER ÉTICO E A AÇÃo POLÍ́TICA: OS FUNDAMENTOS DE UM DEVER DE COOPERAÇÃO INTERNACIONAL NA FILOSOFIA POLÍTICA DE IMMANUEL KANT .405 Ademar Junior Pozzatti

EXTENSÃo E FRAGMENTAÇÃo NO CONTEXTO DA JURISDIÇÃO PENAL INTERNACIONAL .423 Marcus Vinícius Xavier de Oliveira

A DEFINiÇÃo JURÍdiCA DA "COMUNIDADE" .444 Nitish Monebhurrun, Michelle Lucas Cardoso Balbino, Fernanda Castelo Branco Araujo, Othon Pantoja, Míara Bogo Bruno e Cândida Dettenborn Nóbrega 
Comparative Study on Chinese Local Legislation of Science and Technology ProGRESS

LI Xiaoming e LI Yihan

O CONTROLE PENAL DO TRÁFICO DE PESSOAS: CONSTRUÇÃO JURÍDICA, INTERAÇÕES ORGANIZACIONAIS E COOPERAÇÃO INTERNACIONAL

Bruno Amaral Machado e Priscilla Brito Silva Vieira

Desativismo judicial: a extradição Battisti no Supremo Tribunal Federal .505 Francisco Rezek e Israel Paulino

A decisão norte-americana do Caso Myriad: novos paradigmas para a Proteção patenTÁRIA DO CÓDIGO GENÉTICO HUMANO E BIOTECNOLOGIA 514 José Carlos Vaz e Dias e Clarisse De La Cerda 


\title{
Precedentes vinculantes nos Estados Unidos da América e no direito brasileiro: um estudo comparado*
}

\author{
Binding precedents in the United States \\ of America and in the Brazilian Law: a \\ comparative study
}

Patrícia Perrone Campos Mello**

\section{Resumo}

O artigo desenvolve uma análise comparada sobre o significado e o modo de operar com precedentes judiciais no direito norte-americano (pertencente à família do common law) e no direito brasileiro (de origem romano-germânica), com o propósito de identificar categorias e institutos que auxiliem a compreensão da prática brasileira, com base em um país com tradição nessa matéria. Com esse objetivo, três aspectos essenciais da operação com precedentes foram analisados e confrontados: (i) o conteúdo vinculante dos precedentes em cada sistema; (ii) o processo colegiado de decisão das cortes constitucionais; e (iii) a diferenciação entre ratio decidendi e obiter dictum. $\mathrm{O}$ exame dessas categorias revela que não há perfeita correspondência entre os binding precedents norte-americanos e os precedentes vinculantes brasileiros. O próprio significado de precedente vinculante, no Brasil, encontra-se, ainda, substancialmente, indeterminado. Há discussão sobre a eficácia vinculante da ratio decidendi, não se diferencia com precisão ratio decidendi de obiter dictum e o processo decisório da corte constitucional não contribui para o esclarecimento desses elementos. A indeterminação constitui uma ameaça à efetividade da força normativa dos precedentes e indica a necessidade de aperfeiçoamentos institucionais do Judiciário brasileiro, e, sobretudo, de um sistema de formação e de incentivos para que os magistrados adiram à prática.

Palavras-chave: Precedentes vinculantes. Direito comparado. Ratio decidendi.

* Autora convidada

** Mestre e doutora pela Universidade do Estado do Rio de Janeiro - UERJ. Professora da graduação e da pós-graduação stricto sensu do Centro Universitário de Brasília - UniCEUB. Procuradora do Estado do Rio de Janeiro. Email: patricia.mello@stf.jus.br

\section{Abstract}

This study develops a comparative analysis on the meaning and operation of binding precedents in the United States of America (attached to common law tradition) and in the Brazilian Law (attached to civil law tradition). The purpose of the analysis is to identify categories and institutes produced by a country with a long experience on the matter, in order to improve the comprehension of the Brazilian practice. With this purpose, this study examined and compared three fundamental elements of each system: (i) the binding content of precedents; (ii) the collegial decision proce- 
dure of constitutional courts; and (iii) the distinction between ratio decidendi and obiter dictum. In conclusion, it demonstrates that there is not a perfect equivalence between American and Brazilian binding precedents. It also shows that the meaning of binding precedents in Brazil is still undefined: the binding effects of ratio decidendi are controversial, ratio decidendi and obiter dictum distinction is not precise and the collegial decision procedure of Brazilian Supreme Court does not help to clarify these issues. We argue that this scenario threatens the normative force of Brazilian precedents, and that it is necessary to improve our judicial institutions and to introduce incentive systems to induce courts compliance to binding precedents.

Keywords: Binding precedents. Comparative law. ratio decidendi.

\section{INTRODUÇÃO}

O Brasil tem apresentado, desde a promulgação da Constituição de 1988, uma tendência crescente à adoção de precedentes judiciais vinculantes ${ }^{1}$. A Constituição adotou um sistema híbrido de controle da constitucionalidade. Manteve o controle difuso, de inspiração norte-americana, possibilitando a discussão da matéria constitucional, no âmbito de litígios concretos, e previu

1 Toda decisão judicial produz efeitos vinculantes. A maior parte das decisões vinculam apenas aqueles que foram parte na ação. Algumas delas, contudo, além de vincularem as próprias partes estabelecem entendimentos a serem obrigatoriamente observados pelos demais órgãos judiciais, no julgamento de casos futuros e semelhantes. É com este último sentido que se aludirá a precedentes vinculantes neste trabalho. Ainda que o termo vinculante não implique necessariamente, do ponto de vista estritamente técnico, a produção de efeitos para além do processo em que a decisão foi proferida, a prática jurídica consagrou o uso da expressão precedente vinculante para aludir a julgados que produzem efeitos impositivos e gerais para além dos casos em que proferidos e, por isso, é com essa conotação que será utilizada aqui. Em razão da falta de uma cultura de respeito voluntário aos precedentes no Brasil, só se consideraram incluídos nesta categoria aqueles precedentes cujo descumprimento possibilita a propositura de reclamação diretamente no Supremo Tribunal Federal, para cassação da decisão divergente. É que somente nesses casos o caráter impositivo do precedente alcança efetividade, como já observou a doutrina sobre a matéria. É, portanto, com esse significado que o termo precedente vinculante será utilizado neste trabalho. BARROSO, Luís Roberto. O controle de constitucionalidade no direito brasileiro. 7. ed. Rio de Janeiro: Saraiva, 2015. p. 160-161; 235-248; MELLO, Patrícia Perrone Campos. Precedentes: o desenvolvimento judicial do direito no constitucionalismo contemporâneo. Rio de Janeiro: Renovar, 2008. p. 74-113. a possibilidade de apreciação final da questão pelo Supremo Tribunal Federal, por meio de recurso extraordinário. A decisão do STF nessa sede, originalmente, produzia efeitos apenas entre os postulantes, mas havia a possibilidade de suspensão da execução da lei declarada inconstitucional pelo Senado Federal ${ }^{2}$.

A Carta de 1988 promoveu, em paralelo, uma considerável expansão do controle concentrado da constitucionalidade, de origem europeia, por meio de ações propostas diretamente no Supremo, cujo objeto principal, como regra, é aferir a compatibilidade em tese de um ato com a Constituição ${ }^{3}$. Nesse tipo de controle, atribuiu às decisões eficácia vinculante e geral (erga omnes), cuja observância é obrigatória para todos os demais órgãos judiciais ${ }^{4}$. O desrespeito às decisões com tal eficácia se sujeitava, desde a origem, à cassação, por meio de reclamação proposta diretamente ao STF.

Veja-se que, anteriormente à Constituição de 1988, o controle concentrado da constitucionalidade podia ser deflagrado por um único legitimado: o Procurador-Geral da República. Com a nova Carta, o rol de legitimados para a propositura das ações diretas foi bastante ampliado, tendo-se estendido, inclusive, para entidades representativas tais como a Ordem dos Advogados do Brasil, as confederações sindicais, as entidades de classe de âmbito nacional e os partidos políticos ${ }^{5}$. O texto ori-

2 Art. 52: "Compete privativamente ao Senado Federal: [...]; X - suspender a execução, no todo ou em parte, de lei declarada inconstitucional por decisão definitiva do Supremo Tribunal Federal". BRASIL. Constituição (1988). Constituição da República Federativa do Brasil. Disponível em: <www.planalto.gov.br/ccivil_03/constituicao/constituicaocompilado.htm>. Acesso em: 02 dez. 2016.

3 Afirma-se que a apreciação da constitucionalidade ocorre em tese porque a discussão não nasce de um litígio concreto, entre partes que disputam determinado bem. De fato, no Brasil, o controle concentrado é, como regra, associado ao controle principal e abstrato. Mas há exceções, como, por exemplo, a representação interventiva, que instaura controle concentrado no STF, porém realizado em concreto e incidentalmente, tendo por objeto um conflito federativo. SARLET, Ingo Wolfgang; MARINONI, Luiz Guilherme; MITIDIERO, Daniel. Curso de direito constitucional. 4. ed. São Paulo: Saraiva, 2015. p. 1306-1307.

4 As decisões proferidas em controle concentrado da constitucionalidade pelo STF produzem efeitos vinculantes e gerais oponíveis não apenas aos demais órgãos judiciais, mas também à administração pública $\left(\mathrm{CF} / 88\right.$, art. 102 , I, l, c/c $\left.\ 2^{\circ}\right)$. Esse alcance tão amplo dos efeitos gerais produzidos pelos julgados nesta sede não estão presentes em outros precedentes vinculantes, cujos entendimentos se impõem apenas aos demais órgãos judiciais, sem que deixem de se caracterizar como vinculantes. Como essa diferenciação não é essencial para os fins deste trabalho, e para não torná-lo desnecessariamente complexo, optou-se por evitar a alusão a tal particularidade. 5 Art. 103: "Podem propor a ação direta de inconstitucionalidade 
ginal da Constituição previu, como instrumentos dessa modalidade de controle, a ação direta de inconstitucionalidade (ADI), a ação direta de inconstitucionalidade por omissão (ADO) e a arguição de descumprimento de preceito fundamental (ADPF), esta última, contudo, sem contornos definidos ${ }^{6}$.

Com a Emenda Constitucional 3/1993, inseriu-se, no sistema de controle concentrado, a ação declaratória da constitucionalidade - nova modalidade de ação direta igualmente apta a produzir julgados dotados de eficácia vinculante e geral. Mais adiante, a Lei 9.882/1999 dispôs sobre o processo e o julgamento da arguição de descumprimento de preceito fundamental, definindo-a como mais um instrumento desse tipo de controle, com caráter subsidiário quanto às demais ações diretas. Previu-se que a $\mathrm{ADPF}$ seria cabível, sempre que presente a violação de um preceito fundamental da Constituição, se não fosse possível a discussão da matéria por meio das demais ações diretas já previstas no ordenamento ${ }^{7}$. As decisões nela proferidas, também, constituiriam precedente vinculante, tal como ocorria com as demais ações diretas. Notadamente, a expansão do controle concentrado da constitucionalidade ligava-se à possibilidade de produção de precedentes vinculantes pelo Supremo nessa sede, o que não ocorria no caso do controle difuso.

Mais adiante, a Emenda Constitucional (EC) 45/2004 criou, então, a súmula vinculante: verbete for-

e a ação declaratória de constitucionalidade: I - o Presidente da República; II - a Mesa do Senado Federal; III - a Mesa da Câmara dos Deputados; IV - a Mesa de Assembleia Legislativa ou da Câmara Legislativa do Distrito Federal; V - o Governador de Estado ou do Distrito Federal; VI - o Procurador-Geral da República; VII - o Conselho Federal da Ordem dos Advogados do Brasil; VIII - partido político com representação no Congresso Nacional; IX - confederação sindical ou entidade de classe de âmbito nacional". BRASIL. Constituição (1988). Constituição da República Federativa do Brasil. Disponível em: <http://www.planalto.gov.br/ccivil_03/constituicao/ constituicaocompilado.htm>. Acesso em: 02 dez. 2016.

6 Art. 102, $\int 1^{\circ}$ : "A arguição de descumprimento de preceito fundamental, decorrente desta Constituição, será apreciada pelo Supremo Tribunal Federal, na forma da lei”. BRASIL. Constituição (1988). Constituição da República Federativa do Brasil. Disponível em: <http:/ / www.planalto.gov.br/ccivil_03/constituicao/constituicaocompilado.htm>. Acesso em: 02 dez. 2016.

7 A caracterização da subsidiariedade na ADPF, de acordo com a jurisprudência do STF, depende da demonstração do não cabimento de outra ação direta, bem como da necessidade de que a questão seja efetivamente decidida por esta via, ou seja, é necessário demonstrar, ainda, a necessidade de uma decisão que produza efeitos vinculantes e gerais com o alcance dos precedentes proferidos em controle concentrado. BARROSO, Luís Roberto. O controle de constitucionalidade no direito brasileiro. 7. ed. Rio de Janeiro: Saraiva, 2015, p. 335-339. mulado pelo Supremo Tribunal Federal, estabelecendo uma síntese do entendimento constitucional sobre matéria reiteradamente julgada pelo tribunal, cuja observância seria obrigatória para os demais órgãos judiciais e para a administração pública. A partir de então, tornou-se possível conferir efeitos vinculantes e gerais a entendimentos constitucionais reiteradamente proferidos pelo STF em sede difusa. O desrespeito às súmulas vinculantes passou a ensejar a cassação da decisão divergente, por meio de reclamação dirigida diretamente ao Supremo ${ }^{8}$.

A EC 45/2004 introduziu, ainda, um novo requisito de admissibilidade para o recurso extraordinário: a repercussão geral da matéria debatida ${ }^{9}$. Em 2006, o instituto da repercussão geral foi regulamentado pela Lei $11.418 / 2006$, e criou-se o procedimento especial para julgamento de recursos extraordinários repetitivos ${ }^{10}$. O novo procedimento previu que, em caso de diversos recursos sobre idêntica controvérsia, o tribunal a quo selecionaria alguns paradigmas sobre o tema e os remeteria ao STF. Os demais casos seriam sobrestados, de forma que, uma vez reconhecida a repercussão geral dos paradigmas e julgado seu mérito pelo Supremo, a tese constitucional firmada pela Corte fosse aplicada por todos os demais tribunais.

A razão de ser do procedimento especial para julgamento de recursos extraordinários repetitivos em sede difusa era clara: fazer com que o Supremo Tribunal Federal firmasse entendimentos sobre matéria constitucional que fossem replicados pelos órgãos judiciais nos demais casos semelhantes, de modo a reduzir o volume de recursos submetidos a seu exame. Entretanto, o próprio tribunal entendeu não ser cabível reclamação em caso de descumprimento dos entendimentos firmados

8 BRASIL. Constituição (1988). Constituição da República Federativa do Brasil. Disponível em: <http://www.planalto.gov.br/ccivil_03/ constituicao/constituicaocompilado.htm $>$. Acesso em: $02 \mathrm{dez}$. 2016.

9 BRASIL. Constituição (1988). Constituição da República Federativa do Brasil. Disponível em: <http://www.planalto.gov.br/ccivil_03/ constituicao/constituicaocompilado.htm>. Acesso em: $02 \mathrm{dez}$. 2016. Art. 543-A, $\$ 1^{\circ}$, com redação conferida pela Lei 11.418/2006: "Para efeito da repercussão geral, será considerada a existência, ou não, de questões relevantes do ponto de vista econômico, político, social ou jurídico, que ultrapassem os interesses subjetivos da causa”. BRASIL. Lei n. 11.418, de 19 de dezembro de 2006. Disponível em: <https://www.planalto.gov.br/ccivil_03/_ato20042006/2006/lei/111418.htm>. Acesso em: 02 dez. 2016.

10 BRASIL. Lei n. 11.418, de 19 de dezembro de 2006. Disponível em: <https://www.planalto.gov.br/ccivil_03/_ato2004-2006/2006/lei/ 111418.htm>. Acesso em: 02 dez. 2016. 
em repercussão geral ${ }^{11}$. A prática, por sua vez, demonstrou que a inexistência de um mecanismo como a reclamação para impor o respeito aos precedentes do Supremo, em um país sem essa cultura, frustrava a sua efetiva normatividade. De fato, nem sempre os órgãos judiciais vinculados se dispunham a cumpri-los voluntariamente, de modo que, na vigência do antigo Código de Processo Civil, as decisões proferidas em repercussão geral não podiam ser considerados "precedentes vinculantes" em sentido pleno $^{12}$.

Finalmente, em 2015, editou-se o novo Código de Processo Civil (CPC/2015), estabelecendo-se como precedentes vinculantes em matéria constitucional não apenas as decisões proferidas em controle concentrado da constitucionalidade, mas os entendimentos firmados pelo Supremo Tribunal Federal, no controle difuso da constitucionalidade, em sede de repercussão geral e de recurso repetitivo. Passou-se, ainda, a admitir a propositura de reclamação diretamente ao STF (desde que exauridas as instâncias ordinárias), também em caso de descumprimento da interpretação fixada em repercussão geral, podendo a Corte cassar, liminarmente, as decisões judiciais divergentes ${ }^{13}$.

O CPC/2015 contemplou, ainda, o recurso especial

11 V. STF, Pleno, Rcl 7569, rel. Min. Ellen Gracie, DJe, 11.12.2009; Rcl 10.973, rel. Min. Ellen Gracie, DJe, 06.06.2011; Segunda Turma, Rcl 17036 AgR, rel. Min. Teori Zavascki, DJe, 27.04.2016; Segunda Turma, Rcl 16245 AgR-ED, rel. Min. Gilmar Mendes, DJe, 01.09.2015; Segunda Turma, Rcl 17914 AgR, rel. Min. Ricardo Lewandowski, DJe, 04.09.2014.

12 Para um exame da eficácia dos precedentes judiciais no sistema brasileiro, antes e depois do CPC/2015. MELLO, Patrícia Perrone Campos. O Supremo e os precedentes constitucionais: como fica a sua eficácia após o Novo Código de Processo Civil. Universitas Jus, Brasília, v. 26, n. 2, jul./dez. 2015, p. 41-54; WAMBIER, Teresa Arruda Alvim et. al. Primeiros comentários ao novo código de processo civil. São Paulo: Revista dos Tribunais, 2015. p. 1315-1318; 1413-1421; MARINONI, Luiz Guilherme; ARENHART, Sérgio Cruz; MITIDIERO, Daniel. Novo código de processo civil. São Paulo: Revista dos Tribunais, 2015. p. 872-876; 920-921.

13 Art. 988: "Caberá reclamação da parte interessada ou do Ministério Público para: I - preservar a competência do tribunal; II - garantir a autoridade das decisões do tribunal; III - garantir a observância de enunciado de súmula vinculante e de decisão do Supremo Tribunal Federal em controle concentrado de constitucionalidade; IV - garantir a observância de acórdão proferido em julgamento de incidente de resolução de demandas repetitivas ou de incidente de assunção de competência; [...]; \40 As hipóteses dos incisos III e IV compreendem a aplicação indevida da tese jurídica e sua não aplicação aos casos que a ela correspondam". BRASIL. Lei $n$. 13.105, de 16 de marco de 2015. Disponível em: <https://www. planalto.gov.br/ccivil_03/_ato2015-2018/2015/lei/113105.htm>. Acesso em: 2 dez. 2016. repetitivo com procedimento semelhante ao recurso extraordinário repetitivo ${ }^{14}$ e inseriu, no âmbito dos tribunais, dois novos institutos: o incidente de resolução de demanda repetitiva e o incidente de assunção de competência. O primeiro instituto se destina à produção de precedente vinculante sobre matéria repetitiva nos tribunais ${ }^{15}$; o segundo é voltado à produção de precedente vinculante sobre questão com relevância social que ainda não seja objeto de uma multiplicidade de recursos $^{16}$. Em ambos os casos, a observância do precedente será obrigatória e seu descumprimento ensejará reclamação ${ }^{17}$.

O avanço dos precedentes vinculantes no ordenamento jurídico brasileiro pode ser compreendido à luz da necessidade de realização de três valores fundamentais: a segurança jurídica, a isonomia e a eficiência. A observância dos entendimentos firmados pelos tribunais promove, em primeiro lugar, uma maior previsibilidade, estabilidade e continuidade do direito, tendo em vista que a solução aplicada a um caso norteará a solução dos demais casos análogos, reduzindo-se a discricionariedade dos juízes. O respeito aos precedentes assegura, em segundo lugar, que casos idênticos receberão o mesmo tratamento e, portanto, que os diferentes jurisdicionados serão tratados com isonomia ${ }^{18}$. Torna, por fim, mais racional o trabalho do Judiciário e o uso de seus recursos, voltando a energia dos magistrados para as questões que ainda não foram assentadas, reduzindo o número de reformas de decisões pelos tribunais e desestimulando demandas e recursos aventureiros. Esses são os mesmos valores que, de modo geral, justificaram a adoção de precedentes vinculantes no common law ${ }^{19}$.

14 O recurso especial repetitivo foi introduzido no sistema processual brasileiro pelo art. 543-C do CPC/1973, com redação conferida pela Lei 11.672/2008.

15 BRASIL. Lei n. 13.105, de 16 de março de 2015. Disponível em: <https://www.planalto.gov.br/ccivil_03/_ato2015-2018/2015/lei/ 113105.htm>. Acesso em: 2 dez. 2016.

16 BRASIL. Lei n. 13.105, de 16 de março de 2015. Disponível em: <https://www.planalto.gov.br/ccivil_03/_ato2015-2018/2015/lei/ 113105.htm>. Acesso em: 2 dez. 2016.

17 BRASIL. Lei n. 13.105, de 16 de marco de 2015. Disponível em: <https://www.planalto.gov.br/ccivil_03/_ato2015-2018/2015/lei/ 113105.htm>. Acesso em: 2 dez. 2016.

18 Sobre a relação entre isonomia e processo civil. GUEDES, Jefferson Carús. Igualdade e desigualdade: Introdução conceitual, normativa e histórica dos princípios. São Paulo: Revista dos Tribunais, 2014.

19 MELlO, Patrícia Perrone Campos. Precedentes: o desenvolvimento judicial do direito no constitucionalismo contemporâneo. Rio de Janeiro: Renovar, 2008. p. 69-74. 
De todo modo, a instabilidade jurisprudencial e a aplicação de entendimentos antagônicos a situações semelhantes têm sido percebidos como um problema crônico no Brasil não apenas por parte dos jurisdicionados, mas, igualmente, por parte da sua comunidade jurídica. Há muitos anos, buscam-se soluções para um volume exponencialmente crescente de processos, inclusive nos tribunais superiores ${ }^{20}$, a ponto de o Supremo Tribunal Federal ter sido apontado como "o tribunal mais sobrecarregado do mundo" 21 .

Feito o histórico sobre a evolução dos precedentes vinculantes no ordenamento jurídico brasileiro, uma primeira anotação se faz imprescindível: nosso direito possui origem romano-germânica. O sistema romano-germânico caracteriza-se por ter a lei, ou seja, a norma escrita, aprovada pelo legislador, como a principal fonte do direito e por conferir ao precedente judicial, como regra, eficácia, meramente, persuasiva. De fato, essa foi, com alguns temperamentos, a realidade do ordenamento jurídico brasileiro até a entrada em vigor do novo Código de Processo Civil. Consequentemente, o Brasil não dispõe de tradição no manejo de precedentes vinculantes ou na compreensão e reflexão do direito com base nessa categoria ${ }^{22}$.

Por essa razão, o aumento dos casos de precedentes vinculantes é sublinhado pela doutrina como um indicador de que estaríamos experimentando um processo de aproximação entre o nosso sistema e o common law. $\mathrm{O}$ common law é o sistema de direito adotado pelos países de colonização inglesa e tem por característica central o reconhecimento das decisões judiciais como principal fonte do direito. Esse sistema adota o stare decisis ${ }^{23}$, política que determina que as cortes sigam os precedentes estabelecidos pelos tribunais que lhes são, hierarquica-

20 Para um exame da sobrecarga dos tribunais à luz da análise econômica do direito. GICO, Ivo T. A tragédia do judiciário: subinvestimento em capital jurídico e sobreutilização do Judiciário. 2012. Disponível em: < http://works.bepress.com/ivo_teixeira_gico_junior $/ 53 />$. Acesso em: 2 set. 2016.

21 THE ECONOMIST. Brazil's Supreme Court. when less is more. 2009. Disponível em: <http://www.economist.com/ node/13707663>. Acesso em: 2 set. 2016.

22 MELLO, Patrícia Perrone Campos. Precedentes: o desenvolvimento judicial do direito no constitucionalismo contemporâneo. Rio de Janeiro: Renovar, 2008. p. 11-60.

23 Stare decisis deriva da expressão latina stare decisis et non quieta movere, que significa: "deixar quieto o que já foi decidido e não alterá-lo". MELLO, Patrícia Perrone Campos. Precedentes: o desenvolvimento judicial do direito no constitucionalismo contemporâneo. Rio de Janeiro: Renovar, 2008. p. 116-118. mente, superiores, e tem uma tradição consolidada no manejo com precedentes vinculantes.

A afirmação dessa aproximação não se limita ao direito brasileiro. De modo geral, alega-se que os países de origem romano-germânica têm apresentado uma tendência, sobretudo em matéria constitucional, a evoluir para a adoção de precedentes vinculantes ${ }^{24}$; e que, paralelamente, os países que adotam o common law, também, têm demonstrado uma inclinação crescente a recorrer à lei como forma de implementar mudanças sociais rápidas, de assegurar prestações relacionadas ao estado de bem-estar social ou de cumprir compromissos decorrentes do ingresso em comunidades internacionais ${ }^{25}$. Em razão disso, sugere-se que há, em verdade, um processo de aproximação recíproca entre os dois sistemas, marcado por um importante intercâmbio de ideias e de institutos.

O presente trabalho tem o propósito de produzir um estudo comparativo entre o conceito e a forma de operar com precedentes vinculantes no direito constitucional brasileiro e no common law, com ênfase no direito norte-americano. A opção pelo direito norte-americano justifica-se, em primeiro lugar, porque, embora os Estados Unidos da América adotem o common law e tenham, por consequência, uma longa tradição na operação com precedentes vinculantes, dispõem, por outro lado, de uma constituição escrita e rígida ${ }^{26}$. Seus precedentes

24 É o que ocorre hoje, em maior ou menor grau, na Alemanha, na Itália e na Espanha. ALEXY, Robert; DREIER, Ralf. Precedent in the Federal Republic of Germany. In: MACCORMICK, D. Neil; SUMMERS, Robert S.; GOODHART, Arthur (Org.). Interpreting Precedents: a comparative study. England: Dartmouth Publishing Company Limited Ashgate Publishing Limited, 1997. p. 17-65; TARUFFO, Michele; LA TORRE, Massimo. Precedent in Italy. In: MACCORMICK, D. Neil; SUMMERS, Robert S.; GOODHART, Arthur (Org.). Interpreting Precedents: a comparative study. England: Dartmouth Publishing Company Limited Ashgate Publishing Limited, 1997. p. 141-189; RUIZ MIGUEL, Alfonso; LAPORTA, Francisco J. Precedent in Spain. In: MACCORMICK, D. Neil; SUMMERS, Robert S.; GOODHART, Arthur (Org.). Interpreting Precedents: a comparative study. England: Dartmouth Publishing Company Limited Ashgate Publishing Limited, 1997. p. 259-293.

25 Nessa linha, os Estados Unidos da América aprovaram a Lei de Proteção ao Paciente e ao Tratamento a Custo Acessível (Patient Protection and Affordable Care Act), com o propósito de garantir o acesso da população à saúde. E a Inglaterra editou a Lei de Reforma Constitucional de 2005 (Constitutional Reform Act), pela qual criou uma Suprema Corte, situada fora do Parlamento, com a finalidade de reproduzir o sistema tradicional de tripartição de poderes adotado pela Comunidade Europeia. Informações disponíveis em: <http://housedocs.house.gov/energycommerce/ppacacon. pdf $>$ e < http://www.legislation.gov.uk/ukpga/2005/4/contents>. 26 Não se desconhecem as profundas diferenças existentes entre 
voltam-se, portanto, a aplicar uma norma geral, à semelhança de uma lei, o que aproxima o direito constitucional norte-americano, em alguma medida, do modo de operar do sistema romano-germânico. $\mathrm{O}$ sistema norte-americano serviu, ainda, de inspiração para o controle difuso da constitucionalidade brasileira, responsável, atualmente, pelo maior volume de casos julgados pelo Supremo Tribunal Federal. E as decisões e o modo de operar da sua Suprema Corte exercem influência sobre o nosso debate de temas constitucionais e são tidos como uma referência relevante pela jurisprudência e pela doutrina brasileiras ${ }^{27}$.

Acredita-se que a investigação ora proposta é de grande interesse porque, com a vigência do novo Código de Processo Civil, o Brasil precisará adotar novos institutos e ajustar a aplicação do direito a uma realidade em que o uso de precedentes vinculantes foi generalizado. Nessas condições, o estudo da experiência norte-americana pode revelar categorias interessantes, que auxiliarão a compreensão do direito doméstico, e que, nessa medida, ajudarão a definir uma agenda de questões que precisam ser enfrentadas e compostas pelo Judiciário brasileiro. Com esse objetivo, passa-se, a seguir, ao exame da operação com precedentes no direito norte-americano e no direito brasileiro, no que diz respeito a três aspectos essenciais: (i) a definição do teor vinculante dos precedentes, denominado ratio decidendi ou holding; (ii) o processo colegiado de decisão de suas cortes constitucionais; (iii) a delimitação e a força impositiva atribuída aos obiter dicta $^{28}$.

a Constituição de 1988, analítica, abrangente e tantas vezes emendada, e a Constituição norte-americana, vigente desde 1789, antiga, sintética e submetida a poucas alterações. Todavia, o sistema norteamericano é mais próximo do nosso do que o sistema inglês, que sequer se dispõe de uma constituição escrita.

27 SOUZA NETO, Cláudio; SARMENTO, Daniel. Direito constitucional: Teoria, história e métodos de trabalho. Belo Horizonte: Fórum, 2013. p. 450-454.

28 A opção pela metodologia de comparação entre os dois sistemas e a escolha dos aspectos a serem examinados se aproxima, tanto quanto possível, da abordagem desenvolvida em MACCORMICK, D. Neil; SUMMERS, Robert S.; GOODHART, Arthur (Org.). Interpreting precedents: a comparative study. England: Dartmouth Publishing Company Limited Ashgate Publishing Limited, 1997. Seguramente esses não são os únicos aspectos que mereceriam confronto. Outros pontos relevantes para a compreensão de semelhanças e diferenças entre tais sistemas referem-se, a título ilustrativo, ao modo de realizar a distinção entre casos e aos standards a serem observados na superação de julgados. Esses aspectos não serão examinados aqui por demandarem pesquisa autônoma. É importante, ainda, o registro sobre a existência de farto debate na literatura sobre métodos legítimos para estudos de direito comparado, que, de
Há, por fim, uma última razão que justifica o presente estudo. Muitos são os autores que recorrem ao sistema norte-americano para o estudo da matéria. Entretanto, é fundamental compreender que não há uma perfeita correspondência entre os binding precedents norte-americanos e os precedentes vinculantes brasileiros. Como já sinalizado, o direito brasileiro provém de família jurídica diversa, adotou um controle de constitucionalidade híbrido, que, também, sofreu influência europeia e suas instituições enfrentam particularidades e limitações diversas das norte-americanas. Portanto, é importante, também, compreender as profundas diferenças que podem marcar o uso do termo precedentes em cada qual dessas realidades.

\section{O TEOR VINCULANTE DOS PRECEDENTES NOS SISTEMAS EM EXAME}

\subsection{A ratio decidendi no direito norte- americano}

O primeiro aspecto a ser examinado para a compreensão do significado de precedente vinculante nos referidos países diz respeito ao conteúdo ou à parte da decisão judicial que determinará o julgamento de casos futuros. No common law em geral e nos Estados Unidos da América, inclusive, tal conteúdo é denominado ratio decidendi ou holding e corresponde à questão de direito ou ao entendimento jurídico firmado pela corte vinculante para decidir o caso concreto.

Embora a noção de ratio decidendi seja fundamental para a operação com precedentes no common law, há considerável divergência sobre o seu significado ou so-

modo geral, expressam a compreensão acerca da inexistência de um critério perfeito e imune a críticas. Dadas as muitas particularidades, diferenças culturais e institucionais entre os diferentes ordenamentos, a consideração de todos os pontos distintivos implicariam, no limite, a inviabilidade da comparação. Sobre o tema: FREIRE, Alonso Reis Siqueira. A comparação no direito constitucional: metodologias, abordagens, tipos de pesquisa e princípios de inferência orientada para pesquisas small-n. Mimeografado, 2014; CURY, Paula Maria Nasser. Titulo do artigo. Revista de Estudos Constitucionais, Hermenêutica e Teoria do Direito, v. 6, n. 2, p. 176-185, jan./abr. 2016. Especificamente sobre os diferentes significados atribuídos ao termo precedente e às consequentes dificuldades de comparação entre os sistemas. KOMÁREK, Jan. Reasoning with previous decisions. In: ADAMS, Maurice; BOMHOFF, Jacco (Ed.). Practice and theory in comparative law. Cambridge: Cambridge Univesity Press, 2012. p. 49-73. 
bre o método a ser utilizado para identificá-la. Em linhas gerais, a doutrina alude a duas abordagens diferenciadas para a sua definição: o método fático-concreto e o método abstrato-normativo ${ }^{29}$. Segundo a abordagem fático-concreta, a ratio decidendi corresponde à solução extraída pelo tribunal de um conjunto de fatos, podendo ser formulada nos seguintes termos: sempre que presente o fato "A" e o fato "B" deve-se dar à demanda o tratamento " $\mathrm{C}$ ". Para o método fático-concreto, é menos relevante o raciocínio jurídico ou o fundamento utilizado pela Corte para decidir; a ratio decidendi prende-se mais fortemente aos fatos, e não a tal fundamento, e, em virtude disso, tende a ser menos ampla, vinculando apenas demandas muito semelhantes.

$\mathrm{Na}$ perspectiva do método abstrato-normativo, os fundamentos invocados pelas cortes para decidir constituem um elemento essencial para a determinação do teor vinculante do precedente. Segundo esse método, ao solucionarem as lides, os tribunais decidem de modo um pouco mais amplo, tendo em conta não apenas os fatos específicos da demanda em exame, mas também aqueles enquadráveis em uma mesma categoria de similitude, que possivelmente surgirão no futuro. Por essa razão, os fundamentos utilizados pelo tribunal para decidir seriam essenciais para determinar a norma vinculante, bem como o seu nível de generalidade. Tais fundamentos se prestariam a indicar, por exemplo, se os fatos foram tratados pelo tribunal com especificidade

29 ALEXANDER, Larry. Constrained by precedent. Southern California Law Review, Los Angeles, v. 63, p. 1-64, nov. 1989; COLE, Charles D. Stare decisis na cultura jurídica dos Estados Unidos. O sistema de precedente vinculante do common law. Revista dos Tribunais, São Paulo, v. 87, n. 752, p. 11-21, jun. 1998; MALTZ, Earl. The nature of precedent. North Carolina Law Review, Chapel Hill, v. 66, jan.1988, p. 372-376; MARSHALL, Geoffrey. What is binding in a precedent. In: MACCORMICK, D. Neil; SUMMERS, Robert S.; GOODHART, Arthur (Org.). Interpreting precedents: a comparative study. England: Dartmouth Publishing Company Limited Ashgate Publishing Limited, 1997. p. 503-518; MONAGHAN, Henry Paul. Stare decisis and constitutional adjudication. Columbia Law Review, Nova Iorque, v. 88, n. 4, maio 1988, p. 763-766; RE, Edward D. Stare decisis. Revista de Processo, São Paulo, v. 19, n. 73, p.47-54, jan./mar. 1994; SCHAUER, Frederick. Precedent. Stanford Law Review, Palo Alto, v. 39, p. 571-605, fev.1987; SUMMERS, Robert S. Precedent in the United States (New York State). In: MACCORMICK, D. Neil; SUMMERS, Robert S; GOODHART, Arthur (Org.). Interpreting precedents: a comparative study. England: Dartmouth Publishing Company Limited Ashgate Publishing Limited, 1997. p. 355-406; MELLO, Patrícia Perrone Campos. Precedentes: o desenvolvimento judicial do direito no constitucionalismo contemporâneo. Rio de Janeiro: Renovar, 2008. p. 118-131; BUSTAMANTE, Thomas da Rosa. Teoria do precedente judicial: a justificação e a aplicação das regras jurisprudenciais. São Paulo: Noeses, 2012. p. 259-282. e de forma restritiva, ou se foram considerados como componentes de uma categoria mais ampla, à qual a razão de decidir do julgado, também, deve ser aplicada em casos subsequentes.

A título de exemplo, quando o tribunal determina que o produtor de um micro-ondas deve indenizar o consumidor por lhe ter vendido um bem defeituoso e, portanto, por ter descumprido seu dever de protegê-lo contra danos razoavelmente previsíveis, esta conclusão poderia ser considerada um precedente vinculante: (i) apenas para casos de responsabilidade civil que envolvam produtores e consumidores de micro-ondas, (ii) para casos que envolvam qualquer tipo de relação de consumo ou (iii) até mesmo para casos que envolvam a compra e venda de um bem imóvel entre particulares. A definição da amplitude da ratio decidendi dependeria do nível de generalidade com que o tribunal considerou o dever do vendedor de proteger o adquirente contra danos e, portanto, dos argumentos traçados pela maioria do tribunal para decidir.

Consideradas tais ponderações, é razoável afirmar que, no common law, a ratio decidendi corresponde a uma descrição do entendimento jurídico firmado pelo tribunal vinculante como uma premissa necessária ou adequada à solução do caso concreto, à luz das razões adotadas pela maioria ${ }^{30}$. O método fático-concreto e o método abstrato-normativo são complementares para sua definição precisa, uma vez que esta depende: (i) do exame dos fatos relevantes do caso; (ii) da questão jurídica objeto de discussão; e (iii) dos fundamentos invocados pela maioria para decidir. Com base nesses elementos, será possível extrair do julgado a regra ou o princípio de direito que será, obrigatoriamente, utilizado para solucionar casos subsequentes análogos.

Nota-se, assim, que, no common law, a norma de direito - pois a ratio decidendi é uma norma - nasce do caso concreto. Não é formulada em tese, mas à luz do problema. Constitui um comando ou uma generalização extraída a partir do entendimento jurídico firmado

30 Nota-se, portanto, que a ratio decidendi não equivale à íntegra dos fundamentos da decisão. A fundamentação da decisão pode tratar de questões jurídicas que não eram imprescindíveis para a solução do caso (mas a cujo respeito o tribunal quis se manifestar, talvez como sinalização para as demais instâncias). A fundamentação também pode conter entendimento que não obteve a adesão da maioria e que reflete apenas a convicção do redator do julgado. A ratio decidendi é, portanto, uma formulação, uma síntese da exegese adotada pela corte. 
como premissa necessária à composição do conflito entre as partes. É identificada pelo juiz por um raciocínio indutivo que se desenvolve do particular para o geral.

A aplicação do precedente ao julgamento de um novo caso dependerá, por sua vez, de um confronto entre ambos, a fim de verificar se: (i) os fatos relevantes são idênticos, (ii) se ambos colocam a mesma questão de direito e, portanto, (iii) se a razão de decidir o primeiro se presta a decidir adequadamente o segundo ${ }^{31}$. Somente em caso positivo, a solução encontrada no caso paradigma será aplicada à nova ação. Portanto, o modo de operar de um juiz do common law caracteriza-se pelo raciocínio indutivo, analógico e focado no problema.

\subsection{A tese vinculante nos precedentes judiciais brasileiros}

O ordenamento jurídico brasileiro tem raiz romano-germânica por herança portuguesa. Tem, portanto, a norma de direito abstrata, geral e formulada pelo legislador como principal fonte do direito. Em relação à decisão dos conflitos de interesses, o juiz parte do amplo e do abstrato (a lei) para o específico (o caso concreto). A solução das demandas se dá por dedução. A aplicação do direito é pautada por teorias hermenêuticas que orientam e/ou justificam a atribuição de significado ao texto. Nota-se, assim, que o conceito de norma jurídica e os tipos de raciocínio desenvolvidos pelos operadores do direito no sistema romano-germânico e no common law são distintos ${ }^{32}$.

31 A operação pela qual um novo caso é diferenciado do precedente que, a um primeiro exame, parecia vinculá-lo é denominada distinção (distinguish). A discussão aprofundada das técnicas e elementos a serem considerados na distinção entre casos extrapola o objeto deste trabalho. Sobre o tema. MELLO, Patrícia Perrone Campos. Precedentes: o desenvolvimento judicial do direito no constitucionalismo contemporâneo. Rio de Janeiro: Renovar, 2008. p. 202232; LLEWELLYN, Karl. The common law tradition: deciding appeals. Boston: Little, Brown and Company, 1960. p. 77 e ss; SUMMERS, Robert S. Precedent in the United States (New York State). In: MACCORMICK, D. Neil; SUMMERS, Robert S.; GOODHART, Arthur (Org.). Interpreting precedents: a comparative study. England: Dartmouth Publishing Company Limited Ashgate Publishing Limited, 1997. p. 355-405.

32 A descrição da atividade do juiz como mera subsunção do conflito concreto a uma norma objetiva pré-fixada é, atualmente, contestada inclusive no sistema romano-germânico. Grande parte da doutrina reconhece que a norma, regra de direito que solucionará a causa, é o produto da interação entre o enunciado normativo e os fatos da demanda, e que o juiz participa da sua formulação. Essa discussão é prescindível para os fins deste trabalho. V., sobre o tema, BARROSO, Luís Roberto. Curso de direito constitucional contemporâneo. i) Tese vinculante, controle concentrado e controle difuso

Não bastasse tal aspecto, há, no Brasil, a possibilidade de instauração de controle abstrato da constitucionalidade em âmbito judicial. Nesse tipo de controle, a discussão sobre a constitucionalidade da norma não ocorre no âmbito de um caso concreto ou à luz de seus fatos particulares, tal como se dá no common law; ao contrário, seu objeto é a compatibilidade da lei em tese com a Constituição, sem ter por pano de fundo um litígio específico entre duas partes. É o que, geralmente, ocorre nos casos de controle concentrado da constitucionalidade das normas, justamente a via mais tradicional de produção de precedentes vinculantes no Brasil.

Trata-se de diferença fundamental entre o precedente vinculante brasileiro e o precedente vinculante do common law: o precedente brasileiro não necessariamente nasce de um litígio concreto. A questão jurídica que constitui o seu objeto é debatida com considerável grau de generalidade e não dentro do quadro ou dos limites de uma determinada situação fática.

Essa não é, porém, a única diferença marcante relativa ao precedente produzido pelo controle concentrado e abstrato no Brasil. Há, ainda, uma importante divergência no Supremo Tribunal Federal sobre o conteúdo que efetivamente vinculará as demais instâncias nesse tipo de controle. Debate-se, em breves linhas, se a eficácia vinculante dos julgados proferidos em sede concentrada se limita ao dispositivo da decisão proferida na ação direta (segundo o qual a norma " $\mathrm{X}$ " é ou não inconstitucional) ou se alcança, também, o entendimento jurídico que serviu de premissa necessária à afirmação do dispositivo (que corresponderia a uma noção aproximada da ratio decidendi do common law).

Considere-se, a título de ilustração, que diversos Estados da federação tenham decidido legislar, restritivamente, sobre propaganda de cigarro, com o propósito de proteger os consumidores e a sua saúde, e que a lei "X" de um desses Estados teve a sua inconstitucionalidade declarada, em sede de ação direta de inconstitucionalidade, porque o STF firmou o entendimento de que a competência para legislar sobre propaganda é privativa da União ${ }^{33}$. Se apenas o dispositivo da decisão

São Paulo: Saraiva, 2009. p. 193-196.

33 BRASIL. Constituição (1988). Constituição da República Federativa do Brasil. Disponível em: <http://www.planalto.gov.br/ccivil_03/ constituicao/constituicaocompilado.htm>. Acesso em: 02 dez. 2016. 
produzir efeitos vinculantes, isso significa que a lei " $\mathrm{X}$ " de tal Estado não poderá mais ser aplicada. Caso, todavia, o entendimento constitucional firmado pelo STF seja considerado vinculante, isso significa que nenhuma lei estadual que regule propaganda de cigarros poderá ser aplicada, qualquer que seja o ente da federação em questão. Nota-se, assim, que a referida divergência sobre o conteúdo vinculante das decisões proferidas em controle concentrado tem implicações práticas relevantíssimas.

No passado, o Supremo Tribunal Federal apreciou a questão e chegou a reconhecer que a eficácia vinculante e geral da decisão proferida em controle concentrado e abstrato da constitucionalidade alcançava não apenas o dispositivo do julgado, mas também a exegese constitucional que serviu de base para a declaração de inconstitucionalidade. $\mathrm{Na}$ ocasião, esse entendimento foi denominado pelo STF eficácia transcendente dos motivos determinantes da decisão, tendo-se reconhecido que os motivos que justificaram a decisão (e não apenas seu dispositivo) produziam efeitos que ultrapassavam (transcendiam) a ação em que foram afirmados e vinculavam as demais instâncias ${ }^{34}$. Segundo o STF, esse entendimento prestigiava a força normativa da Constituição e a função da Corte de dar a última palavra sobre o seu significado ${ }^{35}$. Confira-se a ementa do acórdão:

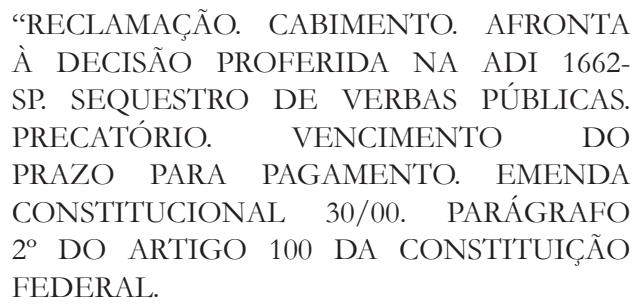

\section{$[\ldots]$.}

2. Ordem de sequestro deferida em razão do vencimento do prazo para pagamento de precatório alimentar, com base nas modificações introduzidas

34 STF, Pleno, Rcl 1.987, rel. Min. Maurício Corres, DJ, 21.05.2004. 35 A assertiva de que compete ao Supremo Tribunal Constitucional "dar a última palavra" sobre o significado da Constituição é, atualmente, problematizada pela teoria dos diálogos constitucionais, que demonstra que uma decisão proferida pelo STF e transitada em julgado não necessariamente encerra o debate sobre determinada matéria, já que os demais Poderes e a opinião pública podem recusarse a cumpri-la ou, eventualmente, mobilizar-se para promover a sua superação por meio de emenda constitucional, o que, possivelmente, levará a questão novamente à apreciação do Tribunal. Por essa razão, afirma-se que o Supremo daria a última palavra sobre o teor da Constituição "a cada rodada". BRANDÃO, Rodrigo. Supremacia judicial versus diálogos constitucionais: a quem cabe a última palavra sobre o sentido da Constituição? Rio de Janeiro: Lumen Juris, 2012. pela Emenda Constitucional 30/2000. Decisão tida por violada - ADI 1662-SP, Maurício Corrêa, DJ de 19/09/2003: Prejudicialidade da ação rejeitada, tendo em vista que a superveniência da EC 30/00 não provocou alteração substancial na regra prevista no $\int 2^{\circ}$ do artigo 100 da Constituição Federal.

3. Entendimento de que a única situação suficiente para motivar o sequestro de verbas públicas destinadas à satisfação de dívidas judiciais alimentares é a relacionada à ocorrência de preterição da ordem de precedência, a essa não se equiparando o vencimento do prazo de pagamento ou a não-inclusão orçamentária.

4. Ausente a existência de preterição, que autorize o sequestro, revela-se evidente a violação ao conteúdo essencial do acórdão proferido na mencionada ação direta, que possui eficácia erga omnes e efeito vinculante. A decisão do Tribunal, em substância, teve sua autoridade desrespeitada de forma a legitimar o uso do instituto da reclamação. Hipótese a justificar a transcendência sobre a parte dispositiva dos motivos que embasaram a decisão e dos princípios por ela consagrados, uma vez que os fundamentos resultantes da interpretação da Constituição devem ser observados por todos os tribunais e autoridades, contexto que contribui para a preservação e desenvolvimento da ordem constitucional. [...]."

O que se denominou eficácia transcendente dos motivos determinantes, então, guardava muita proximidade com o conceito de ratio decidendi do common law. Embora a decisão do Supremo não derivasse de um litígio concreto, entendeu-se que a interpretação do STF sobre a questão constitucional, posta pelo caso, equivalente ao motivo determinante da decisão, tinha de ser seguida por todas as demais instâncias.

Entretanto, posteriormente, a Corte mudou de posição e passou a decidir que, no controle abstrato, apenas o dispositivo do julgado produz eficácia vinculante e geral. A razão de ser da virada jurisprudencial foi, ao que tudo indica, defensiva ${ }^{36}$. O desrespeito aos prece-

36 Nessa linha, ao votar nos autos da Rcl 1.987, o Ministro Marco Aurélio já observara: "Não posso, Senhor Presidente, caminhar nesse sentido, potencializando, a mais não poder, o aspecto prático; potencializando a autoridade dos julgados desta Corte e até mesmo, e já foi ressaltado, engessando o próprio Direito no que vindo à baila novos atos normativos, como foi o caso quanto à Emenda $\mathrm{n}^{\circ} 30$, se terá sempre o caminho aberto para se chegar per salto ao Supremo Tribunal Federal, com a reclamação, a partir da premissa de que o ato praticado desrespeitou fundamento de um julgado da Corte. Não sei onde vamos parar em termos de inviabilização do próprio Supremo Tribunal Federal". A discussão sobre a matéria foi reaberta, então, nos autos da Rcl 4.219, rel. Min. Joaquim Barbosa. Embora seu julgamento tenha sido suspenso e, mais tarde, tenha havido perda superveniente de seu objeto, os votos já proferidos nessa reclamação indicavam a possibilidade de alteração do entendi- 
dentes vinculantes, no controle concentrado, possibilitava (e ainda possibilita) o ajuizamento de reclamação diretamente no STF, para obter a cassação da decisão divergente. Como já demonstrado, se apenas o dispositivo da decisão, sobre uma determinada norma de um certo ente da federação, produzisse efeitos obrigatórios, o volume de reclamações recebidas diretamente pelo Supremo pelo descumprimento do julgado tenderia a ser muito menor do que se os motivos determinantes da decisão também vinculassem as demais instâncias, em relação ao que diz respeito ao julgamento de toda e qualquer norma semelhante, ainda que de outros entes da federação ${ }^{37}$.

Recentemente, contudo, o CPC/2015 trouxe novo regramento acerca do cabimento das reclamações e previu, explicitamente, que caberá reclamação sempre que a tese firmada pelo Supremo Tribunal Federal em controle da constitucionalidade for descumprida ${ }^{38}$. Essa redação sugere que o novo Código pretendeu atribuir efeitos vinculantes à exegese constitucional, ou seja, ao entendimento firmado pelo STF, e não apenas a seu dispositivo.

mento anterior.

37 BRASIL. Supremo Tribunal Federal. Agravo Regimental em Reclamação. Ag. Reg. na reclamação 21.884/SP. Primeira Turma. Relator: Min. Edson Fachin. Brasília, 15 mar. 2016. Disponível em: $<$ www.stf.jus.br/portal/processo/pesquisarProcesso.asp>. Acesso em: 05 nov. 2016.; BRASIL. Supremo Tribunal Federal. Embargos de Declaração no Agravo Regimental na Reclamação. Emb. Decl. no Ag. Reg. na Reclamação 6.416/SP. Primeira Turma. Relator: Ministro Luiz Fux. Brasília, 26 de agosto de 2014. Disponível em: < redir.stf.jus. $\mathrm{br} /$ paginadorpub/paginador.jsp?docTP $=\mathrm{TP} \&$ docID $=6694486>$. Acesso em: 5 nov. 2016.; BRASIL. Supremo Tribunal Federal. Agravo Regimental em Reclamação. Rcl 11477 AgR/CE. Primeira Turma. Relator: Min. Marco Aurélio. Brasília, 29 de maio de 2012. Disponível em: <stf.jusbrasil.com.br/jurisprudencia/22869920/ agreg-na-reclamacao-rcl-11477-ce-stf/inteiro-teor-111144828\#>. Acesso em: 5 nov. 2016.;. BRASIL. Supremo Tribunal Federal. Agravo Regimental na Reclamação. Rcl 3294 AgR/RN. Tribunal Pleno. Relator: Min. Dias Toffoli. Brasília, 3 de novembro de 2011. Disponível em: <http://redir.stf.jus.br/paginadorpub/paginador. jsp?docTP=AC\&docID=629873>. Acesso em: 5 nov. 2016.; BRASIL. Supremo Tribunal Federal. Reclamação. Rcl 3014/SP. Tribunal Pleno. Relator: Min. Ayres Britto. Brasília, 31 de dezembro de 2004. Disponível em: <http://stf.jusbrasil.com.br/jurisprudencia/19150486/reclamacao-rcl-3014-sp-stf>. Acesso em: 5 nov. 2016. 38 "Art. 988. Caberá reclamação da parte interessada ou do Ministério Público para: [...]; III - garantir a observância de enunciado de súmula vinculante e de decisão do Supremo Tribunal Federal em controle concentrado de constitucionalidade; [...]. \4 4o As hipóteses dos incisos III e IV compreendem a aplicação indevida da tese jurídica e sua não aplicação aos casos que a ela correspondam". BRASIL. Lei n. 13.105, de 16 de março de 2015. Disponível em: <www. planalto.gov.br/ccivil_03/_ato2015-2018/2015/lei/113105.htm>. Acesso em: 5 nov. 2016.
A despeito disso, há ministros do STF que, posteriormente à vigência do novo $\mathrm{CPC}$, já manifestaram inclinação no sentido de que a tese, no caso, corresponderia tão-somente ao dispositivo do julgado, no sentido da inconstitucionalidade da norma "X", e não à exegese que lhe serviu de base. É provável que a resistência a atribuir significado diverso à nova norma derive dos mesmos fundamentos que justificaram o entendimento anterior: a preocupação com o recebimento pela Corte, já consideravelmente sobrecarregada, de um grande volume de reclamações ${ }^{39}$.

É válido registrar, ainda, que, com o CPC/2015, a mesma questão se colocará igualmente em caso de repercussão geral. O novo Código previu, expressamente, o cabimento de reclamação contra a decisão que deixar de aplicar a tese firmada pelo Supremo, em sede de repercussão geral, aos demais casos semelhantes. Entretanto, procurou limitar o volume de reclamações propostas, prevendo que seu cabimento só poderá ocorrer após o exaurimento pelas partes das vias ordinárias.

De todo modo, é importante o registro de que não está consolidado no ordenamento jurídico brasileiro um conceito de tese vinculante perfeitamente análogo à concepção de ratio decidendi do common law. Há controvérsia sobre a questão, ao que tudo indica, menos por uma diferença de concepção sobre o modo de operar com precedentes e mais por uma preocupação defensiva quanto ao volume de reclamações que seria recebido pelo STF, caso adotada outra concepção.

Esse fato indica que, embora a reclamação seja um instrumento importante, ela é insuficiente como mecanismo apto a impor o respeito aos precedentes vinculantes. É preciso refletir, portanto, sobre medidas que reforcem a compreensão dos benefícios gerados para o Judiciário com a adoção de entendimentos vinculantes, entre os quais uma substancial redução do volume de processos e a abreviação de seu tempo de tramitação, inclusive nas instâncias vinculadas, o que permitirá que o poder jurisdicional e o convencimento dos magis-

39 Rcl 16927, rel. Min. Rosa Weber, primeira reclamação julgada posteriormente ao início da vigência do CPC/2015, em que os Ministros Luís Roberto Barroso e Luiz Fux salientaram que a redação do novo Código teria tornado explícita a opção por conferir efeitos vinculantes decidendi de todos os julgados, inclusive daqueles proferidos em controle concentrado. Essa parece ser também a inclinação do Ministro Fachin. O Ministro Teori Zavascki, contudo, parece permanecer com o entendimento anterior, que atribui efeitos vinculantes e gerais apenas ao dispositivo da decisão proferida em sede concentrada. 
trados sejam exercidos com maior qualidade e menor sobrecarga. Além disso, a percepção de incremento da previsibilidade, do tratamento isonômico e da eficiência do Judiciário por parte do jurisdicionado reforça a legitimidade e a credibilidade das cortes e de seus membros.

Por fim, é preciso refletir sobre a criação de um sistema de incentivos funcionais para que os juízes respeitem os precedentes, tais quais: o controle de taxas de reversibilidade e de tempo de julgamento de processos por magistrado e a disponibilização de tais dados ao público em geral, entre outras providências ${ }^{40}$.

ii) Tese vinculante e súmula vinculante

Como já mencionado, a EC 45/2004 criou a possibilidade de o Supremo Tribunal Federal produzir súmulas vinculantes, sintetizando, sob a forma de verbete, as teses jurídicas sobre matéria constitucional firmadas em uma multiplicidade de julgados semelhantes. As súmulas vinculantes têm por antecedente histórico os assentos portugueses, enunciados judiciais com caráter normativo, produzidos pela Casa da Suplicação, tribunal português de mais alta hierarquia, cuja finalidade era firmar interpretação, com efeitos obrigatórios, sobre normas controvertidas ${ }^{41}$. Em 1751, foi criado, no Brasil, o Tribunal da Relação do Rio de Janeiro, que produzia assentos sujeitos à aprovação da Casa da Suplicação ${ }^{42}$.

As súmulas vinculantes se diferenciam, substancialmente, dos precedentes vinculantes produzidos no common law. Em primeiro lugar, elas não resultam da atribuição de efeitos normativos automáticos à decisão proferida em um julgado. Ao contrário, dependem da reiteração da tese que constitui seu objeto em mais de uma decisão. Sua edição com tais efeitos normativos, desde que presentes os requisitos constitucionais, fica a critério do Supremo Tribunal Federal. Além disso, as súmulas vinculantes firmam entendimentos em linguagem canônica, produzindo, a partir de decisões judiciais pretéritas, um novo texto, semelhante a uma lei, o qual só se sujeitará a alteração mediante procedimento for-

40 GICO, Ivo T. A tragédia do judiciário: subinvestimento em capital jurídico e sobreutilização do Judiciário. 2012. Disponível em: $<$ http://works.bepress.com/ivo_teixeira_gico_junior/53/>. Acesso em: 2 set. 2016.

41 MELLO, Patrícia Perrone Campos. Precedentes: o desenvolvimento judicial do direito no constitucionalismo contemporâneo. Rio de Janeiro: Renovar, 2008. p. 54-55.

42 TUCCI, José Rogério Cruz e. Precedente judicial como fonte do direito. São Paulo: Revista dos Tribunais, 2004. p. 131-147; 233 e ss. mal deflagrado no âmbito do próprio $\mathrm{STF}^{43}$.

Diferentemente de o que ocorre no caso das súmulas, a ratio decidendi de uma decisão, no common law, ainda quando, claramente, explicitada pela corte vinculada, não deriva de um comando canônico, e terá seu teor redefinido e aperfeiçoado por um processo dialógico que se estabelece entre a corte vinculante e as cortes vinculadas. Parte do significado da ratio decidendi será estabelecido pelas cortes inferiores, ao interpretarem e confrontarem o precedente com novos casos. Quando as instâncias vinculadas aplicam o precedente a uma nova demanda, apenas, parcialmente, semelhante, elas expandem o alcance da sua ratio decidendi, ao passo que, quando estabelecem distinções, reduzem sua amplitude. Tais decisões poderão ser, novamente, submetidas à Suprema Corte, que produzirá um novo entendimento e, assim, sucessivamente. O processo de atribuição e de reatribuição de significado à ratio decidendi é contínuo. Não se conclui com a produção de uma decisão ou de uma síntese pela corte vinculante, diferentemente do que ocorre com um enunciado jurídico cristalizado em uma súmula.

\section{O PROCESSO DECISÓRIO GERADOR DE PRECEDENTES NOS DOIS SISTEMAS}

\subsection{O processo decisório da Suprema Corte norte-americana}

A Suprema Corte norte-americana é composta por 9 (nove) justices indicados pelo Presidente e aprovados pelo Senado. Recebe, em média, até 8.000 (oito mil) processos ao ano e julga, em média, 80 (oitenta) casos a cada período ${ }^{44}$. A principal forma de acesso à Corte ocorre mediante writ of certiorary, por meio do qual as partes requerem a reforma de um julgado proferido pelas instâncias inferiores ${ }^{45}$. Nesse writ, a Corte é livre para

43 BRASIL. Supremo Tribunal Federal. Regimento Interno. 2016. Disponível em: <www.stf.jus.br/portal/cms/verTexto.asp?servico =legislacaoRegimentoInterno $>$. Acesso em: 5 nov. 2016.

44 UNITED STATES. Supreme Court. Frequently Asked Questions (FAQ). Disponível em: <https://www.supremecourt.gov/faq. aspx\#faqgi9>. Acesso em: 20 ago. 2016.

45 EPSTEIN, Lee; KNIGHT, Jack. The choices Justices make. Washington: CQ Press, 1998. p. 26; BAUM, Lawrence. The supreme court. 9. ed. Washington: CQ Press, 2007. p. 88; MELLO, Patrícia Perrone Campos. Nos bastidores do STF. Rio de Janeiro: Forense, 2015. 
definir os casos que apreciará, e sua admissão depende da manifestação favorável de quatro justices ${ }^{46}$.

Superada a etapa da admissão, a Suprema Corte define se o caso será objeto de exame pleno (full consideration) ou de exame sumário (summary consideration). Os casos mais relevantes receberão o primeiro tipo de análise ${ }^{47}$. No exame pleno, após a argumentação oral, os juízes da Suprema Corte reúnem-se em uma conferência privada, que não é acessível aos advogados ou às partes e definem as questões jurídicas a serem enfrentadas, bem como o tratamento que a maioria entende que deve ser dado a elas ${ }^{48}$. Se o Chief Justice (juiz-presidente) integrar a maioria, designará o redator da decisão. Se não a integrar, a definição do redator será efetuada pelo juiz mais sênior que compuser o bloco majoritário ${ }^{49}$.

Ao juiz redator, competirá elaborar um voto que reflita o entendimento prevalecente na Corte. Seu desafio é produzir uma minuta que obtenha a adesão da maioria não apenas quanto à solução a ser dada ao caso, mas, igualmente, quanto às razões jurídicas que a justificam,

p. 178-185.

46 Levantamentos empíricos indicam que casos que versem sobre matéria controvertida nas instâncias inferiores ou que envolvam interesses de governo e/ou de grupos organizados são aqueles com maiores probabilidades de admissão pela Suprema Corte. CALDEIRA, Gregory A.; WRIGHT, John R. Organized interest and agenda setting in the U.S. Supreme Court. American Political Science Review, v. 82, 1988, p. 1120-1123; CROSS, Frank B. Political science and the new legal realism: a case of unfortunate interdisciplinary ignorance. Northwestern University Law Review, v. 92, n. 1, 1997/1998. p. 308.

47 BAUM, Lawrence. The supreme court. 9. ed. Washington: CQ Press, 2007. p. 86-88; FRIEDMAN, Barry. The politics of judicial review. Texas Law Review, v. 84, 2005, p. 284 e ss.; KORNHAUSER, Lewis A.; SAGER, Lawrence G. The one and the many. California Law Review, v. 81, n. 1, p. 1-61, jan. 1993.

48 EPSTEIN, Lee; KNIGHT, Jack. The choices justices make. Washington: CQ Press, 1998. p. 79-98; EPSTEIN, Lee; KNIGHT, Jack. Documenting strategic interaction on the U.S. Supreme Court. 1995. Disponível em: <http://epstein.wustl.edu/research/ conferencepapers.1995APSA.pdf $>$. Acesso em: 20 ago. 2016, p. 17 e ss.; SEGAL, Jeffrey A.; SPAETH, Harold J. The Supreme Court and the attitudinal model revisited. Nova Iorque: Cambridge University, 2002. p. 358 e ss.

49 Como a redação do voto majoritário pode influenciar muito o alcance do precedente que será produzido, não é incomum que o juiz presidente se manifeste nessa primeira reunião de forma estratégica, aproximando seu discurso do entendimento majoritário, ainda que não concorde plenamente com ele, para manter em suas mãos o poder de indicar o redator da decisão. EPSTEIN, Lee; KNIGHT, Jack. Documenting strategic interaction on the U.S. Supreme Court. 1995. Disponível em: <http://epstein.wustl.edu/ research/conferencepapers.1995APSA.pdf>. Acesso em: 20 ago. 2016, p. 18; SEGAL, Jeffrey A.; SPAETH, Harold J. The Supreme Court and the attitudinal model revisited. Nova Iorque: Cambridge University, 2002. p. 367; 372-378. porque, somente se houver convergência quanto a essas últimas, o julgado constituirá, de fato, um precedente vinculante. Quando não se forma uma maioria acerca dos fundamentos que justificam a decisão, não é possível extrair um holding do acórdão $0^{50}$.

Por isso, a primeira minuta de voto do redator é disponibilizada aos demais membros da Suprema Corte para que avaliem seu teor. A partir do seu exame, os justices poderão adotar um dos seguintes comportamentos: (i) concordar com seu conteúdo e aderir ao voto ; (ii) concordar com seu teor, mas ainda assim apresentar voto próprio, que se caracterizará como voto concorrente simples; (iii) concordar com a solução dada ao caso, mas divergir das razões adotadas para tal, produzindo um voto concorrente especial; (iv) discordar da decisão e apresentar voto divergente; (v) aderir a uma concorrência simples, a uma concorrência especial ou ao voto divergente ${ }^{51}$.

É possível e não é incomum que os juízes negociem alterações ao teor ou à linguagem da minuta de voto, como condição para permanecerem ou para passarem a integrar a maioria. Tal negociação, geralmente, ocorre por meio da troca de memorandos entre os justices. Os ajustes de texto e a acomodação dos distintos pontos de vista são compreendidos como parte natural do processo de decisão da Suprema Corte. De acordo com levantamentos empíricos já realizados por seus estudiosos, a maioria das primeiras minutas de voto dos justices sofrem alterações relevantes e tal percentual tende a ser maior quanto maior for a importância do caso ${ }^{52}$.

Esse procedimento pelo qual a maioria tende a se aglutinar em torno do voto do redator, a minoria acompanha o voto divergente e os votos concorrentes delimitam o âmbito de sua discordância, favorece a compreensão dos fundamentos que justificam a decisão majoritária, bem como dos argumentos que animaram a divergência, o que facilitará a delimitação da ratio decidendi que vincula o julgamento de casos semelhantes.

50 SEGAL, Jeffrey A.; SPAETH, Harold J. The Supreme Court and the attitudinal model revisited. Nova Iorque: Cambridge University, 2002. p. 381.

51 EPSTEIN, Lee; KNIGHT, Jack. The choices justices make. Washington: CQ Press, 1998. p. 31; SEGAL, Jeffrey A.; SPAETH, Harold J. The Supreme Court and the attitudinal model revisited. Nova Iorque: Cambridge University, 2002. p. 384 e ss.

52 EPSTEIN, Lee; KNIGHT, Jack. Documenting strategic interaction on the U.S. Supreme Court. 1995. p. 23-34. Disponível em: <http:// epstein.wustl.edu/research/conferencepapers.1995APSA.pdf>. Acesso em: 20 ago. 2016. 


\subsection{O processo decisório do Supremo Tribunal Federal}

O Supremo Tribunal Federal é composto por 11 (onze) ministros, também indicados pelo Presidente da República e aprovados pelo Senado federal, tal como ocorre nos Estados Unidos da América ${ }^{53}$. Nos últimos 5 (cinco) anos, o STF recebeu, em média, aproximadamente, 76.340 (setenta e seis mil trezentos e quarenta) processos ao ano e julgou, em média, 95.980 (noventa e cinco mil novecentos e oitenta) casos em cada perío$\mathrm{do}^{54}$. Decidiu, portanto, um volume de processos mais de mil vezes superior ao volume julgado anualmente pela Suprema Corte norte-americana.

Cerca de $80 \%$ dos casos recebidos pelo STF chegam ao tribunal por meio de recurso extraordinário ou de agravo contra a inadmissão de recurso extraordinário, ambos instrumentos processuais que integram o controle difuso da constitucionalidade ${ }^{55}$. O controle concentrado de constitucionalidade representa, historicamente, menos de 3\% do acervo de processos da Corte $^{56}$.

O Supremo Tribunal Federal não escolhe os casos que julgará. Por isso, ao longo do tempo, o tribunal desenvolveu uma jurisprudência defensiva, por meio da qual estabeleceu requisitos adicionais para o cabimento

53 Afirma-se, contudo, que, no Brasil, a sabatina dos candidatos a ministro não tem o mesmo rigor que a sabatina (e a análise da vida pregressa) sofrida pelos candidatos a justice da Suprema Corte norteamericana. BRANDÃO, Rodrigo. Supremacia judicial versus diálogos constitucionais: a quem cabe a última palavra sobre o sentido da Constituição? Rio de Janeiro: Lúmen Juris, 2012, p. 263-264.

54 BRASIL. Supremo Tribunal Federal. Estatísticas do STF. Disponível em: <http://www.stf.jus.br/portal/cms/ver'Texto.asp?ser vico $=$ estatistica\&pagina $=$ movimentoProcessual $>$. Acesso em: 20 ago. 2016. Do total de casos julgados, a média anual foi de aproximadamente $14 \%$ de decisões colegiadas contra $86 \%$ de decisões monocráticas. Os dados se referem ao período entre 2011 e 2015 inclusive.

55 O percentual considera o período de 2010 a 2014. Não se computaram os dados de 2015 porque estes não foram disponibilizados pelo Tribunal. Os dados de 2016 estão incompletos por se tratar do ano em curso. BRASIL. Supremo Tribunal Federal. Porcentagem de RE, AI e ARE em relação aos processos distribuidos: 1990 a 2014. Disponível em: <http://www.stf.jus.br/portal/cms/verTexto.asp?ser vico=estatistica\&pagina $=$ REAIProcessoDistribuidoAnosAnterior es>. Acesso em: 20 ago. 2016.

56 Esse percentual se baseia em dados referentes ao período de 1988 a 2009. FALCÃO, Joaquim; CERDEIRA, Pablo de Camargo; ARGUELHES, Diego Werneck. I Relatório Supremo em Números: o múltiplo supremo. Rio de Janeiro: Escola de Direito do Rio de Janeiro da Fundação Getúlio Vargas, 2011. Disponível em: <http:// www.fgv.br/supremoemnumeros/relatorios/i_relatorio_do_supremo_em_numeros_0.pdf >. Acesso em: 20 ago. 2016. dos recursos extraordinários e das ações diretas, com o objetivo de reduzir o volume de processos que recebe $^{57}$. Além disso, como já mencionado, a Emenda Constitucional 45/2004 e a Lei 11.418/2006, que a regulamentou, condicionaram a admissão do recurso extraordinário à demonstração de que o feito versa sobre questão que tem repercussão geral para a comunidade. Entretanto, ainda que o reconhecimento de repercussão geral comporte algum nível de apreciação subjetiva, predomina, por ora, o entendimento de que ele não abre uma ampla margem de escolha de casos em favor do Supremo, tal como ocorre com a Suprema Corte norte-americana ${ }^{58}$.

Os casos que chegam ao STF são, como regra, distribuídos por sorteio, aleatória e alternadamente, a cada um dos 11 (onze) ministros que o compõem, ressalvadas as causas para as quais um ministro já esteja prevento ${ }^{59}$. Os poderes do presidente, no que respeita à distribuição de processos e, portanto, à designação de relatores, limitam-se à verificação da ocorrência da prevenção. Cabe ao presidente, contudo, com exclusividade, a definição dos processos que entrarão em pauta (após a solicitação de sua inclusão pelo relator), bem como a escolha dos feitos que serão efetivamente julgados pelo pleno do Supremo a cada sessão, dentre aqueles constantes da pauta $^{60}$, um poder que não é pequeno na realidade de

57 MELLO, Patrícia Perrone Campos. Nos bastidores do Supremo Tribunal Federal. Rio de Janeiro: Forense, 2015. p. 207-209.

58 Vale o registro, contudo, de que o Ministro Luís Roberto Barroso tem defendido, junto à Corte e em trabalhos acadêmicos, que o Supremo Tribunal Federal estabeleça um limite anual de repercussões gerais a serem admitidas, a partir dos casos mais relevantes recebidos no período, como forma de enfrentar a grave sobrecarga de trabalho enfrentada pelo STF e com o propósito de elevar a qualidade dos julgamentos proferidos nesta via, solução que pode ensejar uma alteração substancial do volume de casos apreciados pelo tribunal. BARROSO, Luís Roberto. Reflexões sobre as competências e o funcionamento do Supremo Tribunal Federal. 2014. Disponível em: <http:// www.luisrobertobarroso.com.br/wp-content/uploads/2014/08/ Mudancas-no-funcionamento-do-STF.pdf $>$. Acesso em: 20 ago. 2016.

59 De fato, como regra, a distribuição se dá de forma aleatória e informatizada, por sorteio, salvo quando ocorrer prevenção. Em virtude da prevenção, a competência para julgar determinada questão é mantida com um ministro, quando dela tiver tomado conhecimento em primeiro lugar, mesmo que em outro feito. As hipóteses de distribuição por prevenção estão previstas no Regimento Interno do STF (arts. 69 e ss.). BRASIL. Supremo Tribunal Federal. Regimento Interno. 2016. Disponível em: <www.stf.jus.br/portal/cms/verTexto. asp?servico $=$ legislacaoRegimentoInterno $>$. Acesso em: 5 nov. 2016. 60 O Supremo Tribunal Federal tem a prática de incluir em pauta, para cada sessão plenária, um número de processos muito maior do que o número médio de casos que o Tribunal tem demonstrado ser capaz de julgar. Assim, nem todos os processos incluídos em pauta 
um tribunal que acumula milhares de processos em seu acervo e que pode levar anos para julgá-los ${ }^{61}$.

A declaração da inconstitucionalidade de lei ou de ato normativo é prerrogativa do pleno do Supremo Tribunal Federal, cujas sessões de julgamento são filmadas e transmitidas ao vivo por meio da TV Justiça. Os ministros não têm a prática de se reunirem, reservadamente, para debaterem os casos que apreciarão, tal como ocorre na Suprema Corte norte-americana. Alguns membros do STF disponibilizam, previamente, as minutas de voto nos casos de sua relatoria, mas, raramente, a providência ocorre com antecedência que permita a troca de pontos de vista ou a acomodação de redação, a requerimento de outros ministros dispostos a votar no mesmo sentido. Como cada ministro desconhece como votará seus demais colegas, a tendência de cada qual, sobretudo nos casos mais relevantes, é preparar seu próprio voto escrito e produzir sobre o caso um estudo com profundidade semelhante ao do relator ${ }^{62}$.

Com isso, a sobrecarga sofrida pelos membros do Tribunal é reforçada. Com acervos individuais que variam entre aproximadamente 3.500 (três mil e quinhentos) e 8.300 (oito mil e trezentos) processos ${ }^{63}$, cada ministro despenderá energia e produzirá votos escritos sobre cada caso relevante, eventualmente para decidir no mesmo sentido que o próprio relator. Os acórdãos, que reúnem os votos escritos produzidos por cada membro do tribunal, seus votos orais e, ainda, os debates travados durante o julgamento, somam centenas de páginas de uma leitura extremamente árida ${ }^{64}$.

são julgados e definição daqueles que serão efetivamente decididos acaba dependendo, na prática, da escolha do Presidente do STF.

61 BARROSO, Luís Roberto. Constituição, democracia e supremacia judicial: direito e política no Brasil contemporâneo. Revista da Faculdade de Direito UERJ, v. 2, n. 21, jan./jun. 2012. Disponível em: <http://www.e-publicacoes.uerj.br/index.php/rfduerj/article/ view/1794/2297>. Acesso em: 20 ago. 2016.

62 MELLO, Patrícia Perrone Campos. Nos bastidores do STF. Rio de Janeiro: Forense, 2015. p. 198-210.

63 Os números são pertinentes ao ano de 2016. BRASIL. Supremo Tribunal Federal. Estatísticas do STF. Disponível em: <http:// www.stf.jus.br/portal/cms/verTexto.asp?servico=estatistica\&pagin $\mathrm{a}=$ movimentoProcessual $>$. Acesso em: 20 ago. 2016.

64 O referido processo decisório pode ser classificado como agregativo, externo e de votação em série (seriatim). Agregativo porque a decisão é produto do somatório de votos e não de um julgado de consenso, produto da deliberação de seus membros; externo porque há ampla visibilidade sobre o que ocorre durante o julgamento e sobre como votou cada um dos ministros, não apenas em virtude da publicação desses dados, mas inclusive porque as sessões plenárias de julgamento são televisionadas; em série porque cada membro do Tribunal produz seu próprio voto. MELLO, Patrícia Perrone Cam-
Como a troca de opiniões, no plenário, ocorre muitas vezes depois que o ministro já produziu uma minuta de voto escrito e, como a sessão é pública e televisionada, tornam-se mais difíceis as mudanças de pontos de vista, as moderações de entendimentos e as acomodações que permitiriam a construção de decisões com caráter institucional, que consolidassem, ao menos, o entendimento da maioria.

Em lugar disso, a decisão proferida pelo Supremo Tribunal Federal constitui o resultado do somatório de um mosaico de votos individuais. Não bastasse isso, os entendimentos de cada ministro, até bem pouco tempo, eram colhidos, apenas, quanto ao dispositivo da decisão (provimento ou desprovimento dos recursos, procedência ou improcedência das ações). Não se colhiam seus votos sobre a tese jurídica apta a justificar a decisão em cada caso. Assim, a identificação da interpretação constitucional firmada pelo STF, que corresponde à ratio decidendi de seus julgados, dependia do exame das centenas de páginas do acórdão e dos fundamentos dos votos proferidos por todos os ministros. Não raro, tais ministros não se valiam de argumentos semelhantes para decidir e tornava-se impossível delimitar o entendimento jurídico adotado pela maioria, que deveria servir de norte para as instâncias inferiores.

Percebe-se, por esse relato e a partir do confronto com o processo decisório da Suprema Corte norte-americana, quão disfuncional foi e ainda é o processo decisório do Supremo Tribunal Federal. Como já observado, na realidade brasileira, o volume de casos julgados anualmente pelo STF é mais de mil vezes superior ao volume de casos julgados pela Suprema Corte norte-americana. No entanto, os ministros do Supremo gastam mais energia no julgamento de cada caso relevante porque tendem a produzir longos votos individuais escritos, em lugar de, simplesmente, aderirem em bloco aos votos (majoritário ou vencido) com que concordam. As decisões do Supremo são, excessivamente, extensas e fragmentadas e não delimitam, com clareza, a tese de direito adotada pela maioria. Sem compreender o que, efetivamente, o Tribunal decidiu, os demais órgãos judiciais não podem segui-lo e torna-se impossível estabelecer uma cultura de respeito aos precedentes ${ }^{65}$.

pos. Nos bastidores do Supremo Tribunal Federal. Rio de Janeiro: Forense, 2015. p.171-184; 198-210.

65 BARroso, Luís Roberto. Constituição, democracia e supremacia judicial: direito e política no Brasil contemporâneo. Revista da Faculdade de Direito UERJ, v. 2, n. 21, jan./jun. 2012, p. 39-41. 
Em boa hora, a Corte começou a mudar de atitude e, inicialmente, em sede de repercussão geral, passou a deliberar e a fixar expressamente, durante o julgamento, a tese adotada pela maioria como premissa para a decisão do caso. O novo comportamento teve por base o enunciado normativo do art. $543-\mathrm{A}, \$ 7^{\circ}$, do CPC/1973, que, ao regulamentar o instituto da repercussão geral, previu a publicação de uma súmula da decisão proferida em seu âmbito ${ }^{66}$. Aos poucos essa prática foi se incorporando e vencendo resistências na Corte e, atualmente, vem sendo aplicada, inclusive, para o julgamento das ações diretas de inconstitucionalidade. Trata-se, contudo, de alteração recente e em processo de consolidação.

A definição da tese, em tais circunstâncias, se aproxima da formulação de uma súmula, já que, a partir da decisão concreta, o Tribunal elabora uma norma abstrata que corresponde ao verbete vinculante para as instâncias inferiores. Parece remanescer, contudo, um maior espaço argumentativo no caso da repercussão geral, já que, na aplicação da tese, as instâncias vinculadas poderão revisitar o acórdão que a produziu e reinterpretá-la, à luz de seus fatos e fundamentos, e, ainda, à luz das decisões posteriores que impactem sobre seu sentido. De fato, na repercussão geral, não se define um verbete, em termos canônicos, como ocorre com as súmulas vinculantes, cujo teor só pode ser alterado por meio de procedimento formal junto ao próprio STF.

Portanto, é válido assinalar que o processo decisório do Supremo Tribunal Federal é um outro elemento que diferencia substancialmente o precedente vinculante produzido no sistema brasileiro dos binding precedents produzidos pela Suprema Corte norte-americana.

Disponível em: < http://www.e-publicacoes.uerj.br/index.php/rfduerj/article/view/1794/2297>. Acesso em: 20 ago. 2016; MELLO, Patrícia Perrone Campos. Nos bastidores do STF. Rio de Janeiro: Forense, 2015. p. 198-210; SILVA, Virgílio Afonso da. Deciding without deliberating. International Journal of Constitutional Law, v. 11, n. 3, p. 557-584, jul. 2013; e SILVA, Virgílio Afonso da. O STF e o controle de constitucionalidade: deliberação, diálogo e razão pública. Revista de Direito Administrativo, Rio de Janeiro, n. 250, p. 197-227, 2009; MENDES, Conrado Hübner. Desempenho deliberativo de cortes constitucionais e o STF. In: MACEDO JR., Ronaldo Porto; BARBIERI, Catarina Cortada Barbieri (Org.). Direito e interpretação: racionalidade e instituições. São Paulo: Saraiva, 2011. p. 337-361.

66 Em verdade, a providência era defendida há muito pelo Ministro Luís Roberto Barroso, em trabalhos acadêmicos sobre o assunto. BARROSO, Luís Roberto. Prudências, ousadias e mudanças necessárias ao STF. 2010. Disponível em: <http://www.conjur.com.br/2010dez-28/retrospectiva-2010-prudencias-ousadias-mudancas-necessarias-stf $>$. Acesso em: 20 ago. 2016.

\section{O CONTEÚDO NÃO VINCULANTE DOS PRECEDENTES NOS DOIS SISTEMAS}

\subsection{Os obiter dicta no direito norte-americano}

Uma terceira diferença relevante entre o sistema norte-americano e o brasileiro diz respeito à delimitação do conteúdo não vinculante dos precedentes. No common law, não integram a ratio decidendi (e, portanto, não vinculam os julgados subsequentes) determinadas reflexões, mesmo que efetuadas pela unanimidade dos membros do tribunal, se não forem necessárias ou adequadas para a solução da demanda concreta em exame. Em caso de dúvida, procura-se inverter o significado do entendimento e verificar se, de tal inversão, resulta uma alteração do dispositivo. Se o dispositivo se altera, há indício de que a proposição integra a ratio decidendi. Se não se altera, trata-se de obiter dictum. Consideram-se, ainda, obiter dicta os argumentos constantes da fundamentação do julgado que não tenham sido examinados pelo colegiado ou que, uma vez examinados, não chegaram a ser acolhidos pela maioria dos julgadores.

Os obiter dicta não vinculam porque os precedentes vinculantes são produto da judge made law, ou seja, do direito produzido pelos juízes no exercício da jurisdição. Se uma questão jurídica não precisa ser decidida para solucionar o caso concreto, o entendimento proferido a seu respeito não constitui prestação da tutela jurisdicional e, por consequência, não determina o julgamento de novos casos. O juiz norte-americano não decide em tese ou sem ter sido provocado. Decide à luz do caso concreto. $\mathrm{O}$ conteúdo que vincula as decisões subsequentes é, apenas, aquele imprescindível à decisão do caso paradigma.

A diferenciação entre ratio decidendi e obiter dictum pode se revelar uma tarefa bastante complexa. Basta ter em conta, como exemplo, que uma decisão pode ser tomada com base em mais de um fundamento e que pode surgir uma dúvida sobre se cada qual de tais fundamentos constitui uma bolding autônoma, que justificaria isoladamente a mesma conclusão em casos subsequentes, ou se os fundamentos compõem holdings cumulativos, de forma que, ausente uma das condições, o caso não será governado pelo precedente.

De volta ao exemplo acima, acerca da responsabilidade civil pela venda do micro-ondas que causou le- 
são ao consumidor, pode-se questionar: haverá obrigação de indenizar, sempre, que houver compra e venda, dano, nexo causal, relação de consumo e culpa (já que se mencionou que o dano era razoavelmente previsível)? Ou basta estarem presentes a compra e venda, o dano, o nexo causal e a relação de consumo, podendo estar ausente o elemento culpa (porque a previsibilidade do dano não foi essencial para o reconhecimento da responsabilidade)? E, se estiver ausente o elemento relação de consumo e estiverem presentes todos os demais, haverá responsabilidade? Caso se considere que a menção à relação de consumo foi meramente acidental e não uma condição para o reconhecimento da obrigação de indenizar, a ratio decidendi será muito mais ampla do que nas demais hipóteses e implicará a possibilidade de responsabilizar o vendedor de qualquer bem que gere dano ao comprador.

Ainda que a corte vinculante seja extraordinariamente clara a respeito dos motivos que ensejaram a decisão, a primeira interpretação acerca do teor e do alcance da ratio decidendi será produzida pelos órgãos judiciais vinculados, ao analisarem a sua aplicabilidade a um novo caso. Nessa análise, precisarão fazer uma comparação entre os fatos, a questão jurídica e os fundamentos do precedente e o novo caso que lhes é posto, para verificar se há efetiva semelhança entre ambos ou se o novo caso traz fatos ou coloca questão jurídica diferenciada. No common law, a diferenciação entre ratio decidendi e obiter dictum pode render discussões complexas e, por isso, há particular preocupação com a precisa e detalhada delimitação dos fatos da demanda.

\subsection{Os obiter dicta no sistema brasileiro}

Em relação ao tratamento dado aos obiter dicta pelo sistema brasileiro, nota-se que o Supremo Tribunal Federal atua com pouco rigor na diferenciação entre $r a$ tio decidendi e obiter dictum. Os ministros que integram o STF tendem a adotar uma abordagem maximalista da questão levada a debate em seus votos. Preocupam-se, de modo geral, não apenas com decidir a questão que é posta pelo caso concreto (quando existe um, como ocorre no controle difuso), mas almejam produzir uma análise ampla sobre os institutos que examinam ${ }^{67}$.

67 SUNSTEIN, Cass. One case at a time: judicial minimalism on the Supreme Court. Cambridge: Harvard University, 2001. p. 3-72; THOMAS, E. W. The judicial process: realism, pragmatism, practical reasoning and principals. Nova Iorque: Cambridge University, 2005.
A própria tradição de formação dos bacharéis no Brasil, por herança portuguesa, valoriza a demonstração do conhecimento teórico e do saber enciclopédico, fator que se reflete nas decisões da $\operatorname{Corte}^{68}$. Essa característica é, ainda, reforçada pela vocação do sistema romano-germânico para produzir reflexões sistemáticas e gerais sobre os diversos ramos do direito, com base em princípios e em ideias diretrizes que orientam a hermenêutica de cada conjunto de temas.

Possivelmente, em razão dos referidos aspectos, as decisões proferidas pelo STF demonstram uma preocupação de decidir não apenas a situação imediatamente posta pelo caso, mas eventuais outras que poderiam se relacionar com ela, de forma a sistematizar ou a exaurir os mais diversos aspectos que a questão poderia abranger -mesmo que essa análise não seja efetivamente necessária à solução do caso. Disso resulta eventualmente a pretensão do tribunal de afirmar teses jurídicas mais amplas do que o caso comporta e de pretender que meros dicta vinculem as demais instâncias.

Um exemplo recente auxilia a ilustrar esta postura. Em relação à RE 669.069, submeteu-se ao exame do Supremo Tribunal Federal acórdão que entendeu prescrito o direito de ação da União para se ressarcir de danos causados a um automóvel de sua propriedade, em decorrência de uma colisão de veículos. Em sua defesa, a União alegara que a ação de ressarcimento contra danos causados ao erário público é imprescritível, com base no art. 37, $\$ 5^{\circ}, \mathrm{CF} / 88$, que prevê que: "A lei estabelecerá os prazos de prescrição para ilícitos praticados por qualquer agente, servidor ou não, que causem prejuízos ao erário, ressalvadas as respectivas ações de ressarcimento".

A maioria decidiu negar provimento ao recurso da União, porque concluiu que a ação de ressarcimento nesse caso não era imprescritível. Entre outros argumentos, observou-se que não seria justificável afirmar a imprescritibilidade de toda e qualquer ação de ressarcimento em favor do erário, independentemente do grau

p. 265; SILVA, Alexandre Garrido da. Minimalismo, democracia e expertise: o Supremo Tribunal Federal diante de questões políticas e científicas complexas. Revista de Direito do Estado, Rio de Janeiro, n. 12, p. 110-117, out./dez. 2008.

68 MELLO, Patrícia Perrone Campos. Nos bastidores do STF. Rio de Janeiro: Forense, 2015. p. 169-171; 187-192; VENANCIO FILHO, Alberto. Das arcadas ao bacharelismo: 150 anos de ensino jurídico no Brasil. São Paulo: Perspectiva, 2011; FAORO, Raymundo. Os donos do poder: formação do patronato político brasileiro. São Paulo: Globo, 2012. p. 29-30. 
de reprovabilidade do ato lesivo. Ponderou-se que a prescritibilidade das pretensões é a regra no sistema brasileiro, porque a Constituição teria sido expressa quanto aos delitos que deveriam ser imprescritíveis, incluindo nesta categoria apenas ilícitos de alta gravidade (como o crime de racismo e a ação de grupos armados contra a ordem constitucional e o Estado Democrático ${ }^{69}$ ). Em virtude disso e sendo a imprescritibilidade prevista no art. $37, \int 5^{\circ}$, da Constituição uma exceção, a maioria entendeu que deveria receber interpretação restritiva.

Com base nessa assertiva, o relator defendeu, ainda, que as ações de reparação de danos gerados por ato de improbidade administrativa ou por crime contra a administração pública não deveriam ser incluídas na lógica acima e que seriam imprescritíveis porque se refeririam a ilícitos que, ao contrário dos demais, são dotados de alto grau de reprovabilidade, o que justificaria o tratamento diferenciado na sua opinião. $\mathrm{Na}$ sequência, propôs, como tese emergente do julgado, a afirmação de que: "a imprescritibilidade a que se refere o art. 37, $₫ 5^{\circ}$, da CF diz respeito apenas a ações de ressarcimento de danos ao erário decorrentes de atos praticados por qualquer agente, servidor ou não, tipificados como ilícitos de improbidade administrativa ou como ilícitos penais".

Entretanto, a ação não tratava de ilícito de improbidade ou de ilícito penal. Veja-se que, para decidir o recurso extraordinário, a Corte precisava esclarecer tão somente se a ação para ressarcir danos decorrentes de um acidente de trânsito envolvendo veículo da União era prescritível. Eventual imprescritibilidade do ilícito de improbidade administrativa sequer foi objeto de debate, de forma que os argumentos em favor e contra essa tese não foram ventilados. Ainda que houvesse concordância da unanimidade dos ministros sobre o tema, sua apreciação em tais circunstâncias constituiria mero obiter dictum, ou seja, mera consideração marginal.

Basta verificar que nem a adoção da tese da imprescritibilidade da ação de ressarcimento, em caso de ato de improbidade, nem o entendimento contrário, no sentido da prescritibilidade, alteravam o desfecho do caso do concreto. Essa questão não poderia, por isso, integrar a ratio decidendi do julgado, quer segundo as categorias do common law, quer em respeito ao princípio da inércia da jurisdição, ao princípio da congruência ou ao devido

69 BRASIL. Constituição (1988). Constituição da República Federativa do Brasil. Disponível em: <www.planalto.gov.br/ccivil_03/constituicao/constituicaocompilado.htm>. Acesso em: 20 ago. 2016. processo legal, que regem o processo civil brasileiro ${ }^{70}$. A despeito disso, uma vez ponderado pelo Ministro Luís Roberto Barroso que não seria o caso de incluir na tese a questão pertinente ao ato de improbidade, pelas considerações já expostas, instalou-se uma longa divergência no tribunal. Confira-se trecho dos debates travados entre os ministros sobre o assunto:

“O SENHOR MINISTRO LUÍS ROBERTO BARROSO - [...]. Eu gostaria de adiantar, desde logo, que eu estou de acordo com o voto do Ministro Teori Zavascki naquilo em que decidiu a demanda posta. Portanto, acho que, nas ações de reparação de dano por ilícito civil, a prescritibilidade se impõe, e, no caso concreto, se impõe de acordo com os critérios que Sua Excelência apontou. De modo que não tenho nenhuma dúvida em acompanhá-lo na solução desta lide específica.

Sua Excelência, no entanto, foi um pouco além, preocupado em sistematizar o tema, e, talvez, nós não estejamos ainda em condições de sistematizar o tema. Dentre outras razões, porque a questão da imprescritibilidade em matéria de improbidade, ou mesmo em matéria de crime, ela não foi objeto - eu diria - de um contraditório neste processo. Ou seja, nós não fomos expostos aos diferentes argumentos, alguns deles suscitados agora, pelo Ministro Toffoli e pelo Ministro Gilmar Mendes. E eu não gostaria de ter um pronunciamento do Plenário sobre esta questão importante e delicada da imprescritibilidade, sem um contraditório em que nós pudéssemos considerar todos os argumentos." (Grifou-se)

A essas ponderações, o Ministro Teori Zavascki respondeu da seguinte forma:

"O SENHOR MINISTRO TEORI ZAVASCKI (RELATOR) -Senhor Presidente, Vossa Excelência me permite, em função dos debates, esclarecer algumas coisas?

Primeiro, aqui está, sim, em questão saber se essa imprescritibilidade se refere ou não à ação de improbidade. Aliás, isso ficou muito claro quando se reconheceu a repercussão geral.

Foi exatamente nesse sentido: 'Imprescritibilidade das ações de ressarcimento de danos causados ao erário ainda que o prejuízo não decorra de ato de improbidade administrativa.'[...].

O SENHOR MINISTRO LUÍS ROBERTO BARROSO - Sim, mas o caso concreto envolve um acidente de automóvel.

O SENHOR MINISTRO TEORI ZAVASCKI (RELATOR) - A tese do recurso é que a

70 De acordo com o princípio da inércia da jurisdição, o Poder Judiciário só atua e só aprecia questões se tiver sido provocado, por meio da propositura de uma ação, de forma que não lhe cabe julgar questão que não lhe foi submetida. Segundo o princípio da congruência, a decisão deve se ater a apreciar o que foi pedido pelo réu. 
imprescritibilidade é geral. [...].

O SENHOR MINISTRO MARCO AURÉLIO Ministro, cada dificuldade em seu dia. [...].

O SENHOR MINISTRO RICARDO LEWANDOWSKI (PRESIDENTE) - Eu também tenderia a acompanhar [o Ministro Luís Roberto Barroso], tendo em conta até por uma razão de prudência porque a matéria é muito ampla e...

O SENHOR MINISTRO LUÍS ROBERTO BARROSO - E estamos em dúvida, como Vossa Excelência bem percebeu."

Nota-se, pelos debates, que o que motivava a pretensão de incluir a afirmação acerca da imprescritibilidade da ação de improbidade administrativa na tese era a preocupação de alguns ministros de decidir esta questão, por ser objeto de diversos outros recursos repetitivos, que haviam, inclusive, ficado sobrestados nas instâncias de origem, em virtude da formulação da questão objeto de repercussão geral em termos excessivamente amplos ${ }^{71}$. Alguns ministros acreditavam ser mais importante produzir uma interpretação sistemática e exaustiva sobre o alcance do art. $37, \S 5^{\circ}$, da Constituição do que se ater à questão objeto de debate no caso concreto. Essas considerações levavam parte da Corte a pretender converter mero obiter dictum na tese emergente do recurso.

Outros estudos de direito comparado chegam a resultados semelhantes. Constata-se, de modo geral, um maior rigor na diferenciação entre ratio decidendi e obiter dictum nos países do common law, e uma tendência a não tratar tais categorias com a mesma precisão nos países de tradição romano-germânica ${ }^{72}$. Acredita-se que essa

71 A repercussão geral foi formulada nos seguintes termos: "ADMINISTRATIVO. PRETENSÃO DE RESSARCIMENTO AO ERÁRIO. PRESCRIÇÃO. INTERPRETAÇ̃̃O DA RESSALVA FINAL PREVISTA NO ARTIGO 37, \& 5 $5^{\circ}$, DA CONSTITUIÇÃO FEDERAL. EXISTÊNCIA DE REPERCUSSÃO GERAL. Apresenta repercussão geral o recurso extraordinário no qual se discute o alcance da imprescritibilidade da pretensão de ressarcimento ao erário prevista no artigo $37, \int 5^{\circ}$, da Constituição Federal".

72 Como observam MacCormick e Summers: "no que respeita à metodologia adotada [pelo sistema romano-germânico], quase não há tradição em se diferenciar, de forma sistemática, entre ratio decidendi e obiter dicta - entre bolding e dictum - tal como há no common law”. "Geralmente [nos países do sistema romano-germânico], não se verifica, tal como ocorre no common law, a restrição do elemento vinculante da decisão à questão jurídica examinada à luz dos fatos relevantes do caso concreto. Por isso, o que nós [do common law] chamamos modelo analógico tem um papel muito menor [na operação com precedentes vinculantes do sistema romano-germânico]". MACCORMICK, D. Neil; SUMMERS, Robert S.; GOODHART, Arthur (Org.). Interpreting Precedents: a comparative study. England: Dartmouth Publishing Company Limited Ashgate Publishing Lim- diferença pode ser explicada pela falta de tradição dos últimos na utilização de precedentes vinculantes e pelo viés sistematizador característico do sistema romano-germânico, de que resulta uma preocupação em definir, com precisão, não apenas a regra-geral emergente do caso, mas também as suas exceções, ainda que constituam meros dicta $^{73}$.

\section{Considerações finais}

Nota-se, portanto, que o próprio significado de precedente vinculante, no ordenamento jurídico brasileiro, e de binding precedent, no direito norte-americano, e a forma de operá-los guardam pontos de diferenciação importantes, que, ao que tudo indica, derivam dos sistemas jurídicos - romano germânico ou common law - em que tais direitos deitam suas raízes, das fontes do direito a que, tradicionalmente, reconheceram maior valor, das práticas de interpretação e de aplicação do direito que neles se consolidaram, da modelagem das suas instituições e dos desafios por elas enfrentados. Tais pontos de diferenciação são sintetizados a seguir.

1. No common law, de modo geral, e no direito norte-americano, em particular, o precedente é compreendido como um entendimento jurídico delimitado à luz dos fatos de um caso concreto e da questão de direito que colocam. No direito brasileiro, o precedente vinculante não emerge necessariamente de um caso concreto. Pode ser gerado em sede de controle concentrado da constitucionalidade, em que se produz um exame, em abstrato, da compatibilidade de uma norma infraconstitucional com a Constituição, sem que tal exame derive de um conflito de interesses envolvendo duas partes que defendem direitos próprios e antagônicos. Em consequência, os precedentes vinculantes produzidos em controle concentrado tendem a se firmar em razões de decidir amplas e abstratas.

2. No common law, o teor vinculante do precedente, que determinará como casos semelhantes, devem

ited, 1997. p. 536-537. (tradução nossa).

73 Ainda de acordo com MacCormick e Summers, os diversos pontos em que se identificaram diferenças na operação com precedentes entre o sistema romano-germânico e o common law são sintomáticos de uma concepção a seu respeito que os considera "algo diverso de ou menos do que uma fonte formal do direito e que, por essa razão, tem uma força normativa inferior" MACCORMICK, D. Neil; SUMMERS, Robert S.; GOODHART, Arthur (Org.). Interpreting Precedents: a comparative study. England: Dartmouth Publishing Company Limited Ashgate Publishing Limited, 1997. p. 539. (tradução nossa). 
ser julgados, é designado ratio decidendi ou bolding, e corresponde ao entendimento jurídico que constituiu a premissa necessária ou adequada à solução do caso concreto, à luz de seus fatos e das razões adotadas pela maioria da corte. No direito brasileiro, há concordância quanto à atribuição de efeitos vinculantes à parte da decisão que afirma a constitucionalidade ou inconstitucionalidade da norma. Contudo, ainda não está consolidada, no âmbito do Supremo Tribunal Federal, a concepção que reconhece efeitos vinculantes e gerais, também, à ratio decidendi das suas decisões; ou seja, não está consolidado no STF o entendimento de que a premissa necessária ou adequada à afirmação da constitucionalidade ou da inconstitucionalidade de uma norma também produz efeitos vinculantes e gerais.

3. $\mathrm{Na}$ Suprema Corte norte-americana, a aglutinação dos entendimentos dos ministros em torno do voto majoritário, do voto divergente e de eventuais concorrências favorece a identificação da ratio decidendi da decisão. No Supremo Tribunal Federal, como cada ministro produz seu próprio voto, com razões de decidir individuais, e como, até bem pouco tempo, não se colhiam votos a respeito dos fundamentos reconhecidos pela maioria como aptos a justificar a decisão, a ratio decidendi do julgado não era explicitada com clareza, o que comprometia a sua efetividade como diretriz hermenêutica para as demais instâncias.

4. Atualmente, encontra-se em fase de consolidação no STF a prática de definir, ao final do julgamento, a tese jurídica adotada pelo tribunal como premissa necessária para decidir. Essa inovação no processo decisório do STF favorece a identificação da ratio decidendi e facilitará a operação com precedentes judiciais em matéria constitucional. Todavia, o alcance dos efeitos vinculantes das decisões do Tribunal permanece pendente de definição. $O$ Tribunal precisa determinar, inclusive à luz do novo Código de Processo Civil, se tais efeitos abrangem apenas a declaração da constitucionalidade ou inconstitucionalidade de determinado ato ou se alcançam também a ratio decidendi adotada como fundamento para tal declaração.

5. No common law, ratio decidendi e obiter dictum são diferenciados com rigor. Ainda que determinada matéria seja apreciada pela maioria, a conclusão a seu respeito só integrará a ratio decidendi e, portanto, só produzirá efeitos obrigatórios se constituir premissa necessária ou adequada a solucionar o caso concreto. No direito brasileiro, não há tradição na diferenciação entre ratio decidendi e obiter dictum $\mathrm{e}$ trata-se do assunto com considerável imprecisão. A falta de técnica na diferenciação de tais conceitos favorece o exercício de atividade normativa e em tese pelo Supremo Tribunal Federal, sem observar princípios elementarmente ligados à prestação da tutela jurisdicional, tais quais o princípio da inércia da jurisdição, o princípio da congruência e o princípio do devido processo legal. Como a questão objeto de obiter dicta não é aquela cujo debate é imprescindível para a solução do caso concreto, não é recomendável que se produza a seu respeito um precedente vinculante, porque, nessas condições, haveria o risco de o Supremo decidir sem estabelecer um amplo contraditório sobre o assunto e, portanto, com um nível inadequado de informação, que poderia ensejar instabilidade jurisprudencial e alterações de entendimentos no futuro.

Percebe-se, pelas considerações acima, que as diferenças identificadas entre o sistema norte-americano e o brasileiro no trato dos precedentes são importantes e indicam que não há uma perfeita equivalência entre os binding precedents norte-americanos e os precedentes vinculantes brasileiros. Sem uma definição precisa sobre o teor vinculante dos precedentes no Brasil, sem um processo decisório consolidado que explicite o entendimento adotado pela maioria e sem uma formulação minimamente adequada para diferenciar ratio decidendi $\mathrm{e}$ obiter dicta, há considerável indeterminação sobre a própria concepção do que vem a ser o nosso precedente vinculante, indeterminação, que, por óbvio, ameaça a sua efetividade.

Identificaram-se, ainda, ao longo da pesquisa que serviu à elaboração deste artigo, alguns comportamentos paradoxais no Supremo Tribunal Federal. De fato, ao mesmo tempo em que alguns de seus membros resistem a atribuir à ratio decidendi teor vinculante, pretendem fixar teses que sejam seguidas pelas demais instâncias a respeito de entendimento que constitui mero obiter dictum. A primeira postura implica restrição do alcance do teor vinculante do precedente; a segunda importa uma ampliação desmedida deste.

A prática demonstrou que, sem a previsão do cabimento de reclamação per saltum, diretamente para o tribunal vinculante, com o propósito de cassar a decisão divergente, os precedentes não são observados pelas demais instâncias. No entanto, justamente o fato de ser cabível a reclamação, associado ao temor de gerar ainda maior sobrecarga para o STF, leva, ao menos parte dos seus ministros, a reduzir o alcance do teor vinculante dos julgados à mera declaração da constitucionalidade ou inconstitucionalidade da norma, e a deixar de fora de tais efeitos a exegese constitucional que serviu de premissa para tal entendimento.

Em síntese, tem-se um círculo vicioso: sem a reclamação, os efeitos vinculantes não se concretizam; com a reclamação, o Tribunal age defensivamente e reduz o 
escopo vinculante dos precedentes, transmitindo às instâncias inferiores a mensagem de que podem desconsiderar a exegese constitucional fixada pela Corte. Nessas condições, o Supremo continua prisioneiro da sua sobrecarga. Fica claro que, embora seja um instrumento importante, a reclamação é insuficiente para assegurar o respeito aos precedentes e que é preciso refletir sobre um sistema de formação e de incentivos que motive os magistrados a tal observância.

\section{REFERÊNCIAS BIBLIOGRÁFICAS}

ALEXANDER, Larry. Constrained by precedent. Southern California Law Review, Los Angeles, v. 63, p. 1-64, nov. 1989.

ALEXY, Robert; DREIER, Ralf. Precedent in the Federal Republic of Germany. In: MACCORMICK, D. Neil; SUMMERS, Robert S.; GOODHART, Arthur L. (Org.). Interpreting Precedents: a comparative study. England: Dartmouth Publishing Company Limited Ashgate Publishing Limited, 1997.

BARROSO, Luís Roberto. Constituição, democracia e supremacia judicial: direito e política no Brasil contemporâneo. Revista da Faculdade de Direito UERJ, Rio de Janeiro, v. 2, n. 21, jan./jun. 2012. Disponível em: <http:// www.e-publicacoes.uerj.br/index.php/rfduerj/article/ view/1794/2297>. Acesso em: 20 ago. 2016.

BARROSO, Luís Roberto. Curso de direito constitucional contemporâneo. São Paulo: Saraiva, 2009.

BARROSO, Luís Roberto. O controle de constitucionalidade no direito brasileiro. 7. ed. Rio de Janeiro: Saraiva, 2015.

BARROSO, Luís Roberto. Reflexões sobre as competências e o funcionamento do Supremo Tribunal Federal. 2014. Disponível em: <http://www.luisrobertobarroso.com.br/ wp-content/uploads/2014/08/Mudancas-no-funcionamento-do-STF.pdf>. Acesso em: 20 ago. 2016.

BARROSO, Luís Roberto. Prudências, ousadias e mudanças necessárias ao STF. 2010. Disponível em: <http://www. conjur.com.br/2010-dez-28/retrospectiva-2010-prudencias-ousadias-mudancas-necessarias-stf $>$. Acesso em: 20 ago. 2016.

BAUM, Lawrence. The supreme court. Washington: CQ Press, 2007.

BRANDÃO, Rodrigo. Supremacia judicial versus diálogos constitucionais: a quem cabe a última palavra sobre o sentido da Constituição? Rio de Janeiro: Lúmen Juris, 2012.

BUSTAMANTE, Thomas da Rosa. Teoria do precedente judicial: a justificação e a aplicação das regras jurisprudenciais. São Paulo: Noeses, 2012.

CALDEIRA, Gregory A.; WRIGHT, John R. Organized interest and agenda setting in the U.S. Supreme Court. American Political Science Review, v. 82, 1988.

COLE, Charles D. Stare decisis na cultura jurídica dos Estados Unidos. O sistema de precedente vinculante do common law. Revista dos Tribunais, São Paulo, v. 87, n. 752, jun. 1998.

CROSS, Frank B. Political science and the new legal realism: a case of unfortunate interdisciplinary ignorance. Northwestern University Law Review, v. 92, n. 1, p. 251-326, 1997/1998.

EPSTEIN, Lee; KNIGHT, Jack. Documenting strategic interaction on the U.S. Supreme Court. 1995. Disponível em: <http://epstein.wustl.edu/research/ conferencepapers.1995APSA.pdf $>$. Acesso em: 20 ago. 2016.

EPSTEIN, Lee; KNIGHT, Jack. The choices Justices make. Washington: CQ Press, 1998.

FALCÃO, Joaquim; CERDEIRA, Pablo de Camargo; ARGUELHES, Diego Werneck. I Relatório Supremo em Números: o múltiplo supremo. Rio de Janeiro: Escola de Direito do Rio de Janeiro da Fundação Getúlio Vargas, 2011. Disponível em: <http://www.fgv.br/supremoemnumeros/relatorios/i_relatorio_do_supremo_em_ numeros_0.pdf>. Acesso em: 20 ago. 2016.

FAORO, Raymundo. Os donos do poder: formação do patronato político brasileiro. São Paulo: Globo, 2012.

FREIRE, Alonso Reis Siqueira. A comparação no direito constitucional: metodologias, abordagens, tipos de pesquisa e princípios de inferência orientada para pesquisas small-n. Mimeografado, 2014.

FRIEDMAN, Barry. The politics of judicial review. Texas Law Review, v. 84, p. 257, 2005.

GICO, Ivo T. A tragédia do judiciário: subinvestimento em capital jurídico e sobreutilização do Judiciário. 2012. Disponível em: < http://works.bepress.com/ivo_teixeira_gico_junior/53/>. Acesso em: 2 set. 2016.

GUEDES, Jefferson Carús. Igualdade e desigualdade: introdução conceitual, normativa e histórica dos princípios. 
São Paulo: Revista dos Tribunais, 2014.

LLEWELLYN, Karl. The common law tradition: deciding appeals. Boston: Little, Brown and Company, 1960.

KOMÁREK, Jan. Reasoning with previous decisions. In: ADAMS, Maurice; BOMHOFF, Jacco (Ed.). Practice and theory in comparative law. Cambridge: Cambridge Univesity Press, 2012. p. 49-73.

KORNHAUSER, Lewis A.; SAGER, Lawrence G. The one and the many. California Law Review, v. 81, n. 1, p. 1-61, jan. 1993.

MALTZ, Earl. The nature of precedent. North Carolina Law Review, Chapel Hill, v. 66, jan. 1988.

MARINONI, Luiz Guilherme; ARENHART, Sérgio Cruz; MITIDIERO, Daniel. Novo código de processo civil. São Paulo: Revista dos Tribunais, 2015.

MARSHALL, Geoffrey. What is binding in a precedent. In: MACCORMICK, D. Neil; SUMMERS, Robert S.; GOODHART, Arthur (Org.). Interpreting precedents: a comparative study. England: Dartmouth Publishing Company Limited Ashgate Publishing Limited, 1997.

MACCORMICK, D. Neil; SUMMERS, Robert S.; GOODHART, Arthur (Org.). Interpreting Precedents: a comparative study. England: Dartmouth Publishing Company Limited Ashgate Publishing Limited, 1997.

MENDES, Conrado Hübner. Desempenho deliberativo de cortes constitucionais e o STF. In: MACEDO JR., Ronaldo Porto; BARBIERI, Catarina Cortada Barbieri (Org.). Direito e interpretação: racionalidade e instituições. São Paulo: Saraiva, 2011.

MONAGHAN, Henry Paul. Stare decisis and constitutional adjudication. Columbia Law Review, Nova Iorque, v. 88, maio 1988.

MELLO, Patrícia Perrone Campos. Nos Bastidores do STF. Rio de Janeiro: Forense, 2015.

MELLO, Patrícia Perrone Campos. O Supremo e os precedentes constitucionais: como fica a sua eficácia após o Novo Código de Processo Civil. Universitas Jus, Brasília, v. 26, n. 2, jul./dez. 2015.

MELLO, Patrícia Perrone Campos. Precedentes: o desenvolvimento judicial do direito no constitucionalismo contemporâneo. Rio de Janeiro: Renovar, 2008.

RE, Edward D. Stare decisis. Revista de Processo, São Paulo, v. 19, n. 73, jan./mar. 1994.
RUIZ MIGUEL, Alfonso; LAPORTA, Francisco J. Precedent in Spain. In: MACCORMICK, D. Neil; SUMMERS, Robert S.; GOODHART, Arthur (Org.). Interpreting Precedents: a comparative study. England: Dartmouth Publishing Company Limited Ashgate Publishing Limited, 1997.

SARLET, Ingo Wolfgang; MARINONI, Luiz Guilherme; MITIDIERO, Daniel. Curso de direito constitucional. 4. ed. São Paulo: Saraiva, 2015.

SCHAUER, Frederick. Precedent. Stanford Law Review, Palo Alto, v. 39, p. 571-605, fev. 1987.

SEGAL, Jeffrey A.; SPAETH, Harold J. The Supreme Court and the attitudinal model revisited. Nova Iorque: Cambridge University, 2002.

SILVA, Alexandre Garrido da. Minimalismo, democracia e expertise: o Supremo Tribunal Federal diante de questões políticas e científicas complexas. Revista de Direito do Estado, Rio de Janeiro, n. 12, out./dez. 2008.

SILVA, Virgílio Afonso da. Deciding without deliberating. International Journal of Constitutional Law, v. 11, n. 3, p. 557-584, jul. 2013.

SILVA, Virgílio Afonso da. O STF e o controle de constitucionalidade: deliberação, diálogo e razão pública. Revista de Direito Administrativo, Rio de Janeiro, n. 250, p. 197-227, 2009.

SOUZA NETO, Cláudio; SARMENTO, Daniel. Direito constitucional: teoria, história e métodos de trabalho. Belo Horizonte: Fórum, 2013

SUMMERS, Robert S. Precedent in the United States (New York State). In: MACCORMICK, D. Neil; SUMMERS, Robert S.; GOODHART, Arthur (Org.). Interpreting precedents: a comparative study. England: Dartmouth Publishing Company Limited Ashgate Publishing Limited, 1997.

SUNSTEIN, Cass. One case at a time: judicial minimalism on the supreme court. Cambridge: Harvard University, 2001

TARUFFO, Michele; LA TORRE, Massimo. Precedent in Italy. In: MACCORMICK, D. Neil; SUMMERS, Robert S.; GOODHART, Arthur (Org.). Interpreting Precedents: a comparative study. England: Dartmouth Publishing Company Limited Ashgate Publishing Limited, 1997.

THE ECONOMIST. Brazil's supreme court. when less is more. 2009. Disponível em: <http://www.economist. 
com/node/13707663>. Acesso em: 2 set. 2016.

THOMAS, E. W. The judicial process: realism, pragmatism, practical reasoning and principals. Nova Iorque: Cambridge University, 2005.

TUCCI, José Rogério Cruz e. Precedente judicial como fonte do direito. São Paulo: Revista dos Tribunais, 2004.

VENANCIO FILHO, Alberto. Das arcadas ao bacharelismo: 150 anos de ensino jurídico no Brasil. São Paulo: Perspectiva, 2011.

WAMBIER, Teresa Arruda Alvim et. al. Primeiros co- mentários ao novo código de processo civil. São Paulo: Revista dos Tribunais, 2015.

\section{Agradecimento}

Agradeço ao Professor Alonso Reis Siqueira Freire pela interlocução acadêmica e pelas críticas e sugestões que possibilitaram o aperfeiçoamento deste artigo, embora seu conteúdo final seja da minha exclusiva responsabilidade. 
Para publicar na Revista de Direito Internacional, acesse o endereço eletrônico www.rdi.uniceub.br ou www.brazilianjournal.org.

Observe as normas de publicação, para facilitar e agilizar o trabalho de edição. 